\title{
Review \\ Chronic Effects of Imidacloprid on Honey Bee Worker Development-Molecular Pathway Perspectives
}

\author{
Yun-Ru Chen ${ }^{1}\left(\mathbb{D}\right.$, David T. W. Tzeng ${ }^{2}$ and En-Cheng Yang ${ }^{1, * \mathbb{D}}$ \\ 1 Department of Entomology, National Taiwan University, Taipei 10617, Taiwan; milkingroom@gmail.com \\ 2 School of Life Sciences, The Chinese University of Hong Kong, Hong Kong 999077, China; \\ allqwdd@gmail.com \\ * Correspondence: ecyang@ntu.edu.tw; Tel.: 886-2-3366-9640
}

check for updates

Citation: Chen, Y.-R.; Tzeng, D.T.W.; Yang, E.-C. Chronic Effects of Imidacloprid on Honey Bee Worker Development-Molecular Pathway Perspectives. Int. J. Mol. Sci. 2021, 22, 11835. https://doi.org/10.3390/ ijms222111835

Academic Editor: R.M.M. Haenen

Received: 8 October 2021

Accepted: 28 October 2021

Published: 31 October 2021

Publisher's Note: MDPI stays neutral with regard to jurisdictional claims in published maps and institutional affiliations.

Copyright: (c) 2021 by the authors. Licensee MDPI, Basel, Switzerland. This article is an open access article distributed under the terms and conditions of the Creative Commons Attribution (CC BY) license (https:// creativecommons.org/licenses/by/ $4.0 /)$.

\begin{abstract}
Sublethal dosages of imidacloprid cause long-term destructive effects on honey bees at the individual and colony levels. In this review, the molecular effects of sublethal imidacloprid were integrated and reported. Several general effects have been observed among different reports using different approaches. Quantitative PCR approaches revealed that imidacloprid treatments during the adult stage are expressed as changes in immuneresponse, detoxification, and oxidation-reduction response in both workers and queens. In addition, transcriptomic approaches suggested that phototransduction, behavior, and somatic muscle development also were affected. Although worker larvae show a higher tolerance to imidacloprid than adults, molecular evidence reveals its potential impacts. Sublethal imidacloprid treatment during the larval stage causes gene expression changes in larvae, pupae, and adults. Transcriptome profiles suggest that the population and functions of affected differentially expressed genes, DEGs, vary among different worker ages. Furthermore, an early transcriptomic switch from nurse bees to foragers was observed, suggesting that precocious foraging activity may occur. This report comprehensively describes the molecular effects of sublethal dosages of imidacloprid on the honey bee Apis mellifera. The corresponding molecular pathways for physiological and neurological responses in imidacloprid-exposed honey bees were validated. Transcriptomic evidence suggests a global and sustained sublethal impact of imidacloprid on honey bee development.
\end{abstract}

Keywords: sublethal dosage; imidacloprid; honey bee; bumble bee; molecular effect

\section{Introduction}

Neonicotinoids, also known as neonics, are a class of neuroactive pesticides derived from nicotine [1,2]. Their systematic and highly water-soluble nature makes them one of the most commonly used pesticides worldwide [3,4]. Systemic pesticides can be absorbed into plants and transported throughout plant tissues [3,4]. Insects and other pests will be affected after consuming neonics-absorbed plants or any other contaminated sources. As a class of neuroactive pesticides, neonicotinoids act on the nicotinic acetylcholine receptor (nAChR), permanently bind to nerve cells, block neurotransmission, and cause nerve overstimulation. Poisoned insects show symptoms of twitching, paralysis, and eventually death [5-7]. Neonics can be applied to seed coatings to prevent storage pests or soil applications to control plant-sucking insects such as aphids and scale insects [3]. Although they are one of the most commonly used pesticides, increasing scientific evidence suggests that environmental residue levels of neonicotinoids cause long-term negative impacts on human-maintained honey bee colonies and wild bees around the world [8-15].

For honey bees, foragers are in contact with pesticides during foraging and are the first affected. Those who survive the poisonous pesticides then return to the beehive with neonicotinoid-contaminated nectar and pollen. Nurse bees, larvae, and even queens are consequently threatened by sublethal neonicotinoids through the consumption of pesticidecontaminated food [16-21]. Mitchell et al. (2017) examined honey samples worldwide 
and found that approximately $75 \%$ of the honey samples contained at least 1 neonic, $45 \%$ of them contained more than 2 neonics, and $10 \%$ of the samples contained more than 4 neonics [19]. This report clearly demonstrates that pollinators around the world are under the threat of pesticides, especially neonicotinoids. To protect pollinators, the outdoor usage of 3 neonicotinoids, imidacloprid, thiamethoxam, and clothianidin, has been banned by the European Union [22] to stop the severe, accumulative damages they generate. The effects of imidacloprid, one of the most widely used neonicotinoids, are discussed in this review.

The lethal dose/concentration of imidacloprid in the honey bee Apis mellifera has been widely surveyed, and the levels vary among different regions and seasons (Table 1). In Italy, the acute oral toxicity (AOT) $\mathrm{LD}_{50}$ value for imidacloprid at $24 \mathrm{~h}$ is $118.74 \mathrm{ng} /$ honey bee, and at 48 and $72 \mathrm{~h}$, it is 90.09 and $69.68 \mathrm{ng} /$ bee, respectively [23]. In France, the $\mathrm{LD}_{50}$ (oral application) at $24 \mathrm{~h}$ is $5 \mathrm{ng} /$ bee [24], while the $\mathrm{LD}_{50}$ (oral application) at 48 and $72 \mathrm{~h}$ is $57 \pm 28 \mathrm{ng} / \mathrm{bee}$ and $37 \pm 10 \mathrm{ng} /$ bee, respectively [25]. The oral $\mathrm{LD}_{50}$ at $72 \mathrm{~h}$ ranged from 20 to $81 \mathrm{ng} / \mathrm{bee}$ in Germany, the United Kingdom, and the Netherlands [26]. In Egypt, the $\mathrm{LC}_{50}$ (oral application) under laboratory conditions is 3 parts per billion (ppb) at $24 \mathrm{~h}$ and $0.6 \mathrm{ppb}$ at $48 \mathrm{~h}$, while the $\mathrm{LD}_{50}$ (topical application) is 29 and $26 \mathrm{ng} / \mathrm{bee}$ at 24 and $48 \mathrm{~h}$, respectively [27]. Compared to adults, honey bee larvae can tolerate higher dosages of imidacloprid at $\mathrm{LD}_{50}=4.17 \mu \mathrm{g}$ and $\mathrm{LC}_{50}=138.84$ parts per million (ppm) [28] Different levels of pesticide sensitivity among different regions may be correlated with environmental factors, such as climate conditions [29], processes of breeding [30], as well as individual differences [31,32]. The level of imidacloprid residue in honey bee bread and wax varies among different areas, from $19.7 \mathrm{ppb}$ to $912 \mathrm{ppb}$ [33]. The concentrations of imidacloprid in dead bees vary from 12 to $223 \mathrm{ng} / \mathrm{g}$ dead bee [34]. Imidacloprid residue in bee bread/wax may generate lethal effects if the level is high, and the risk from low residue levels is still a concern. Although a few reports suggest that realistic field doses of imidacloprid pose a low risk for honey bees [35,36], scientific evidence has strongly suggested that a residue level of imidacloprid does not cause immediate death but does generate negative impacts on the ecological sustainability of honey bees, as the impact of chronic pesticide exposure can damage the whole colony or population and even pass to the next generation rather than being limited to individual effects $[15,19,35]$. 
Table 1. $\mathrm{LD}_{50}$ and $\mathrm{LC}_{50}$ results for imidacloprid in honey bees (Apis mellifera).

\begin{tabular}{|c|c|c|c|c|c|c|c|c|}
\hline & $\begin{array}{l}\text { Oral LD50a } \\
\text { (ng Per Bee) }\end{array}$ & $\begin{array}{l}\text { Contact LD50 } \\
\text { (ng Per Bee) }\end{array}$ & Oral LC50a (ppm) & Test Period & Honey Bee & Tested Areas & Hours & Reference \\
\hline & NA & 40 & NA & $\mathrm{NA}$ & $\mathrm{NA}$ & USA & 24 & [37] \\
\hline & $5.4(5.2-1.6)$ & $23.8(22.3-25.3)$ & NA & NA & Apis mellifera mellifera & & 24 & \multirow[b]{3}{*}{ [24] } \\
\hline & $4.8(4.5-5.1)$ & $24.3(22.0-26.6)$ & \multirow[b]{2}{*}{ NA } & \multirow[b]{2}{*}{ NA } & Apis mellifera mellifera & \multirow[b]{2}{*}{ France } & \multirow[b]{2}{*}{48} & \\
\hline & $6.5(4.7-8.3)$ & $12.8(9.7-15.9)$ & & & $\begin{array}{l}\text { Apis mellifera } \\
\text { caucasica }\end{array}$ & & & \\
\hline & 20 & $104(83.0-130)$ & \multirow{6}{*}{ NA } & Jul-99 & \multirow{6}{*}{ NA } & The Netherlands I & \multirow{6}{*}{72} & \multirow{6}{*}{ [26] } \\
\hline & 81 & $61.0(26.0-90.0)$ & & May-00 & & Germany II & & \\
\hline & 81 & $50.0(9.1-71.0)$ & & May-00 & & United Kingdom I & & \\
\hline & 81 & $42.0(20.0-59.0)$ & & May-00 & & Germany III & & \\
\hline & 81 & $42.9(34.6-53.2)$ & & May-00 & & Germany IV & & \\
\hline & 81 & $74.9(61.8-90.9)$ & & Jul-00 & & Germany V & & \\
\hline & $57 \pm 28$ & \multirow[b]{2}{*}{ NA } & \multirow[b]{2}{*}{ NA } & \multirow[b]{2}{*}{ NA } & \multirow[b]{2}{*}{ NA } & \multirow[b]{2}{*}{ France } & 48 & \multirow[b]{2}{*}{ [25] } \\
\hline & $37 \pm 10$ & & & & & & 72 & \\
\hline & $3.7(2.6-5.3)$ & $81(55.0-119.0)$ & \multirow{5}{*}{$\mathrm{NA}$} & \multirow{5}{*}{ NA } & \multirow{5}{*}{ NA } & UK & \multirow{5}{*}{48} & \multirow{5}{*}{ [2] } \\
\hline & $>21.0$ & 230.3 & & & & Netherlands & & \\
\hline & 40.9 & $\mathrm{nt}$ & & & & \multirow{3}{*}{ Germany } & & \\
\hline & $11.6(7.3-18.3)$ & $242.6(173.3-353.4)$ & & & & & & \\
\hline & $21.2(15.0-29.6)$ & $59.7(39.1-92.7)$ & & & & & & \\
\hline & NA & $17.9(9.2-31.5)$ & NA & Jun to Sep-99 & NA & USA & 24 & [38] \\
\hline & 30.6 & $\mathrm{NA}$ & $\mathrm{NA}$ & $\mathrm{NA}$ & $\mathrm{NA}$ & France & 48 & [39] \\
\hline & $25.4 \pm 22.8$ & $\mathrm{NA}$ & $\mathrm{NA}$ & $\mathrm{NA}$ & $\mathrm{NA}$ & France & 48 & [40] \\
\hline & 118.74 & \multirow{3}{*}{ NA } & \multirow{3}{*}{ NA } & \multirow{3}{*}{ NA } & \multirow{3}{*}{ NA } & \multirow{3}{*}{ Italy } & 24 & \\
\hline & 90.09 & & & & & & 48 & [23] \\
\hline & 69.68 & & & & & & 72 & \\
\hline & & 29 & 0.003 & & & & 24 & \\
\hline & NA & 26 & 0.0006 & NA & NA & Egypt & 48 & [27] \\
\hline larvae & $4170(2960-5850)$ & NA & $138.84(98.20-196.30)$ & NA & $\mathrm{NA}$ & USA. & 72 & {$[28]$} \\
\hline & & & NA & NA & NA & Taiwan & 268 & [41] \\
\hline
\end{tabular}


Contamination with a sublethal dosage of imidacloprid causes similar but different effects on nurse bees and foragers. For nurse bees, exposure to a sublethal dosage/concentration of imidacloprid impairs their olfactory-associated learning ability and reduces their activity and social interaction [42-44]. The acini of the hypopharyngeal glands of workers with 20 to $30 \mathrm{ppb}$ imidacloprid treatment are reduced in size to $14.5 \%$ and $16.3 \%$ for 9 - and 14 -dayold nurse bees, respectively [45]. For foragers, exposure to sublethal imidacloprid dosages shortens their lifespan, permanently impairs olfactory-associated learning ability, and alters foraging behavior and foraging frequency [39,46-53]. In addition, respiratory rhythm and metabolic rate are affected. The duration of the bursting pattern of abdominal ventilation movement (AVM) shows a 59.4\% increase in the interburst interval and a 56.99\% decrease in AVM burst duration [45]. Exposure to $5 \mathrm{ppb}$ imidacloprid significantly increases the metabolic rate of foragers at $25^{\circ} \mathrm{C}$ but not at 30 and $35^{\circ} \mathrm{C}$ [54]. Imidacloprid exposure also weakens the immune system and the ability of honey bees to protect against parasites. Newly emerged workers showed a reduction in hemocyte density, encapsulation response, and antimicrobial activity after exposure to $1 \mathrm{ppb}$ or $10 \mathrm{ppb}$ imidacloprid [55]. A synergetic effect is observed in the combination of microsporidia and imidacloprid. Exposure to a sublethal level of imidacloprid causes the elevation of Nosema spore numbers, and honey bees showed a high individual mortality rate and energetic stress in the presence of both agents $[56,57]$. Neurologically, sublethal concentrations of imidacloprid exposure during the larval stage cause a reduction in synaptic density in the mushroom body, the brain region responsible for olfactory and visual functions, consequently causing impairment of olfaction-related learning behavior $[41,58]$. These impairments consequently may make workers vulnerable, even reducing worker lifespan and resulting in colony collapse.

\section{The Effects of Sublethal Dosages of Imidacloprid Exposure during the Adult Stage from a Molecular Perspective}

Behavioral, physiological, and neurological changes may be associated with the expression of corresponding genes, or related molecular regulatory pathways. To confirm this, several studies used qPCR to examine the expression of target genes, to ensure the molecular effects on encoded genes, such as detoxification, antioxidant enzyme production, and immune response [59-62]. Exposure to 5, 20, and $100 \mathrm{ppb}$ imidacloprid for 7 weeks induced the differential expression of GSTD1 [59]. Exposure to $1 \mu \mathrm{L}$ of $20 \mathrm{ppb}(0.02 \mathrm{ppm})$ imidacloprid through topical treatment changed the mRNA expression level of P450 superfamily, immunity, and development-related genes, in workers. More specifically, genes, related to development, antioxidant enzyme coding (catalase, superoxide dismutase (SOD), and thioredoxin peroxidase), and immunity (apidaecin and Amel $\backslash$ LRR) were downregulated at $7 \mathrm{~d}$ post-treatment [60]. De Smet et al. examined the expression of genes, related to immune end-products, vitellogenin, and detoxification enzymes of honey bees raised either in the laboratory (in cages) or in the field after consuming pollen patties containing $5 \mathrm{ppb}$ and $200 \mathrm{ppb}$ imidacloprid. Their results suggest that honey bees show different responses in different environments. Most of the tested immunity- and vitellogenin-related genes, were downregulated in cage-raised bees at both treatment concentrations. In contrast, field bees showed different expression patterns, where $5 \mathrm{ppb}$ imidacloprid treatment generated little or no effect and $200 \mathrm{ppb}$ treatment caused an upregulation in the immune response [61]. The expression of vitellogenin-related genes, also was upregulated in bees exposed to imidacloprid under field conditions. Most detoxification enzymes were downregulated after $10 \mathrm{~d}$ of exposure to imidacloprid in caged honey bees, with a significant downregulation of CYP9Q3. Conversely, most detoxification enzymes were upregulated under field conditions after $20 \mathrm{~d}$ of $200 \mathrm{ppb}$ imidacloprid exposure, with significant upregulation of CYT P450 and CYP9Q3. Some genes, were upregulated after $10 \mathrm{~d}$ but at low levels. Exposure to lower concentrations of imidacloprid under field conditions had little or no effect on the expression levels of the tested detoxification genes, [61]. Gregorc et al. examined the expression of 10 honey bee antioxidant genes, related to pesticide toxicity from 5 or $10 \mathrm{ppb}$ imidacloprid and found upregulation of 3 and 4 antioxidant-related genes, respectively [62] (Table 2a). 


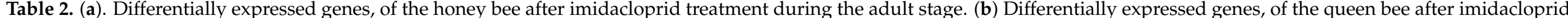
treatment during the adult stage. (c) Differentially expressed genes, of honey bees after imidacloprid treatment during the larval stage.

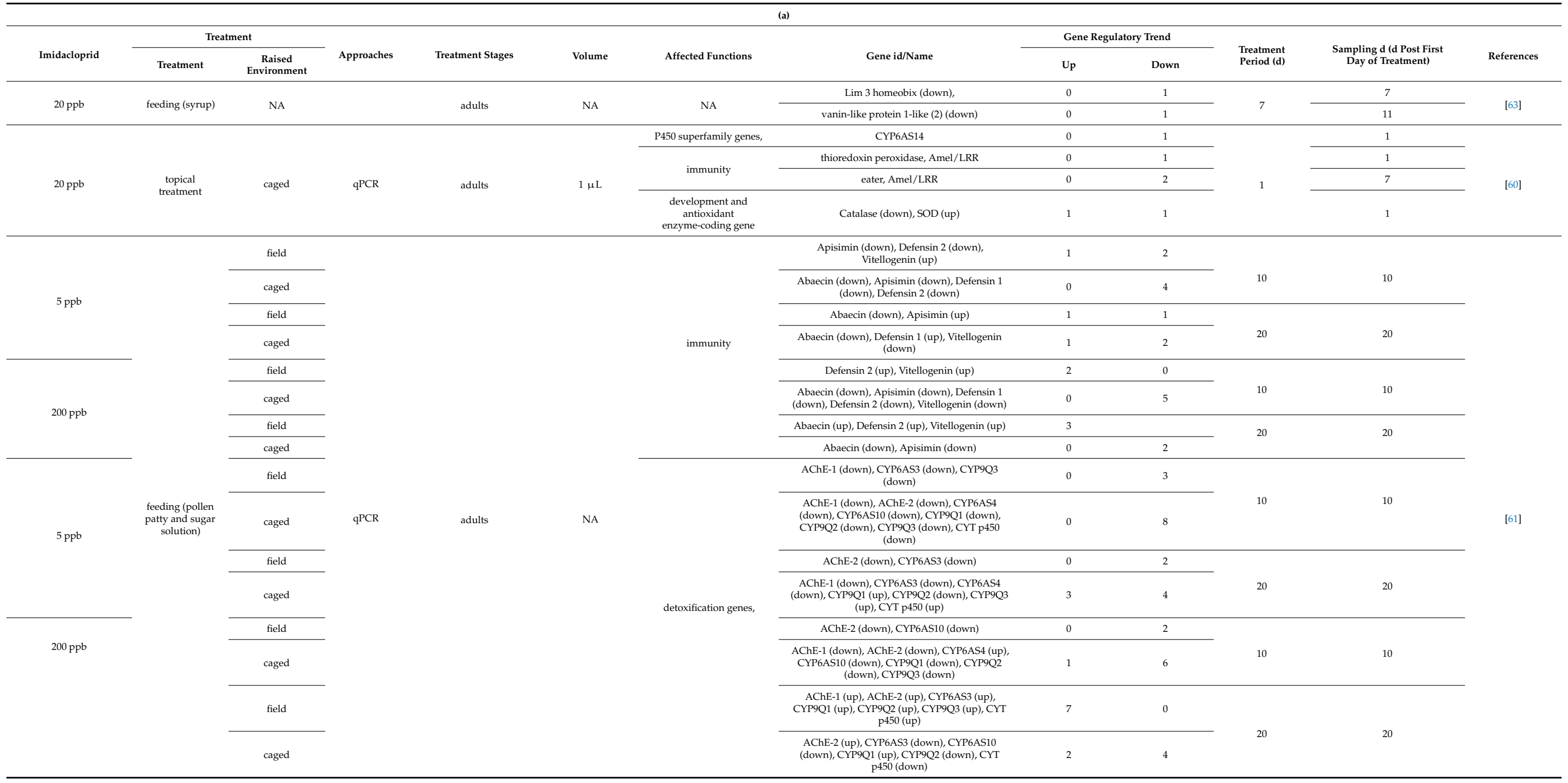


Table 2. Cont.

\begin{tabular}{|c|c|c|c|c|c|c|c|c|c|c|c|c|}
\hline $5 \mathrm{ppb}$ & & & & & & & & & & & & \\
\hline $20 \mathrm{ppb}$ & sugar syrup & caged & $\mathrm{aqPCR}$ & adults & $\mathrm{NA}$ & detoxification enzyme & GstD1 & 1 & 0 & 7 weeks & 7 weeks & [59] \\
\hline $100 \mathrm{ppb}$ & & & & & & & & & & & & \\
\hline \multirow{8}{*}{$10 \mathrm{ppb}$} & \multirow{8}{*}{$\begin{array}{c}\text { feeding, } \\
\text { (sucrose } \\
\text { solution, } 5 \% \% \\
\text { wt } / \text { wt) }\end{array}$} & \multirow{8}{*}{ caged } & \multirow{8}{*}{ NGS } & \multirow{8}{*}{ adults } & \multirow{8}{*}{$\mathrm{NA}$} & total DEGs 509 & \multirow{8}{*}{ NA } & 160 & 349 & \multirow{8}{*}{8} & \multirow{8}{*}{8} & \multirow{8}{*}{ [64] } \\
\hline & & & & & & ribosomal protein & & 28 & 0 & & & \\
\hline & & & & & & phototransduction & & & & & & \\
\hline & & & & & & visual perception & & & & & & \\
\hline & & & & & & photoreceptor & & & & & & \\
\hline & & & & & & actin binding & & \multicolumn{2}{|c|}{ NA } & & & \\
\hline & & & & & & actin cytoskeleton & & & & & & \\
\hline & & & & & & $\begin{array}{l}\text { somatic muscle } \\
\text { development }\end{array}$ & & & & & & \\
\hline $5 \mathrm{ppb}$ & \multirow[b]{2}{*}{$\begin{array}{l}\text { feeding (food } \\
\text { patty) }\end{array}$} & \multirow[b]{2}{*}{ caged } & \multirow[b]{2}{*}{ qPCR } & \multirow[b]{2}{*}{ adults } & \multirow[b]{2}{*}{$\mathrm{NA}$} & antioxidant genes, & Cat (down), MsrA (down), TrxR1 (down) & 0 & 3 & 10 & 10 & \multirow[b]{2}{*}[62]{} \\
\hline $10 \mathrm{ppb}$ & & & & & & antioxidant genes, & $\begin{array}{l}\text { Cat (up), TrxR1 (up), SelK (up), MsrB (up), Sod2 } \\
\text { (down) }\end{array}$ & 4 & 1 & & & \\
\hline \multirow{9}{*}{$20 \mathrm{ppb}$} & \multirow{9}{*}{$\begin{array}{l}\text { feeding (sucrose } \\
\text { solution, } 30 \% \% \\
\text { wt/wt) }\end{array}$} & \multirow{9}{*}{ caged } & \multirow{9}{*}{ NGS } & \multirow{9}{*}{ adults } & \multirow{9}{*}{$\mathrm{NA}$} & total DEGs & 131 & 1 & 130 & 11 & 11 & \multirow{9}{*}{ [53] } \\
\hline & & & & & & $\begin{array}{l}\text { chemosensory- } \\
\text { related genes, }\end{array}$ & $\begin{array}{c}\text { GB46225, GB46227, GB46230, GB53372, GB16006, } \\
\text { GB50003 }\end{array}$ & 0 & 6 & & & \\
\hline & & & & & & $\begin{array}{l}\text { immune and } \\
\text { detoxification response }\end{array}$ & 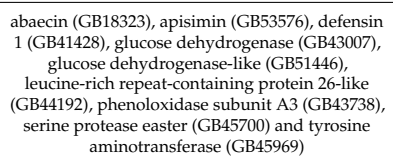 & 0 & 8 & & & \\
\hline & & & & & & $\begin{array}{c}\text { insecticide } \\
\text { resistance-related gene }\end{array}$ & 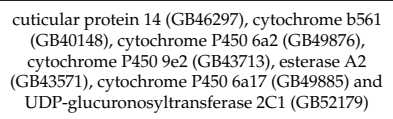 & 0 & 7 & & & \\
\hline & & & & & & oxidation-reduction & $\begin{array}{l}\text { GB52785, GB44549, GB43007, GB555515, GB498776, } \\
\text { GB50655, GB43713, GB51446, G550178, GB49885 }\end{array}$ & 0 & 10 & & & \\
\hline & & & & & & iron ion & GB55515, GB49876, GB50655, GB43713, GB49885 & 0 & 5 & & & \\
\hline & & & & & & oxidoreductase activity & $\begin{array}{l}\text { GB52785, GB44549, GB43007, GB55515, GB49876, } \\
\text { GB50655, GB43713, GB51446, GB50178, GB498855 }\end{array}$ & 0 & 10 & & & \\
\hline & & & & & & behavioral response & $\begin{array}{l}\text { SLC18A2 (GB50003), melanopsin (GB141643), } \\
\text { aquaporin } 4 \text { (GB41240), PRKACB (GB48362) }\end{array}$ & 0 & 4 & & & \\
\hline & & & & & & phototransduction & GB41297, GB51068 & 0 & 2 & & & \\
\hline
\end{tabular}


Table 2. Cont.

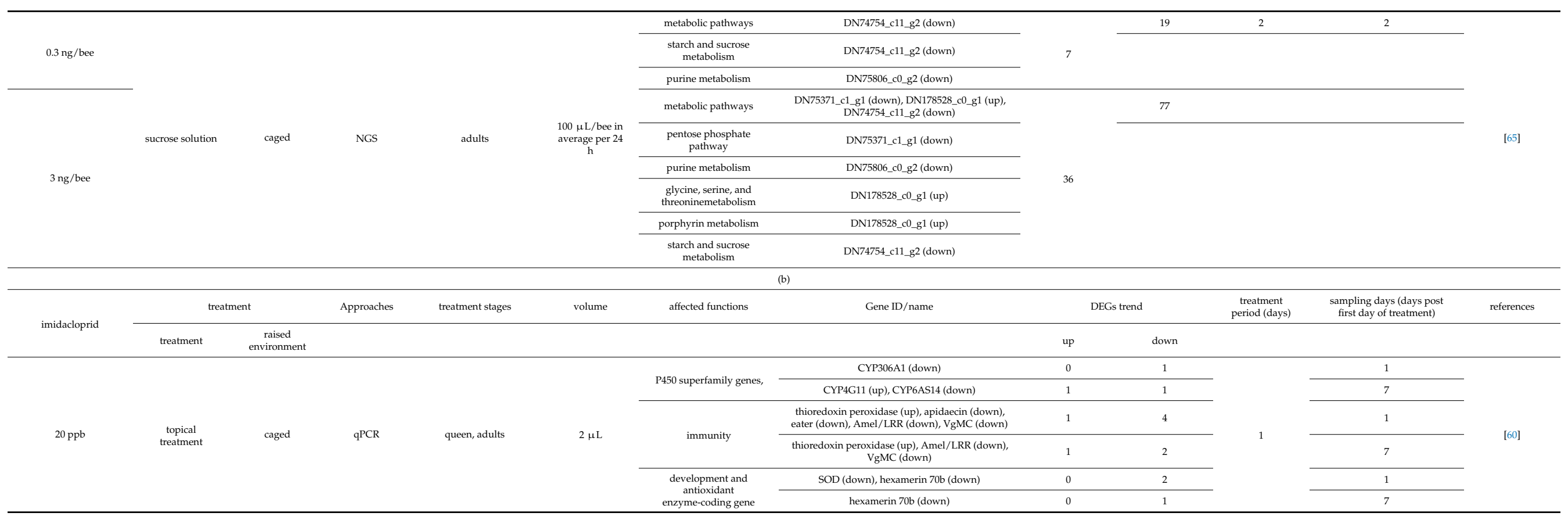


Table 2. Cont.

\begin{tabular}{|c|c|c|c|c|c|c|c|c|c|c|c|c|c|}
\hline \multicolumn{14}{|c|}{ (c) } \\
\hline \multirow[b]{2}{*}{ imidacloprid } & \multicolumn{2}{|c|}{ treatment } & \multirow[b]{2}{*}{ Approaches } & \multirow{2}{*}{$\begin{array}{l}\text { treatment } \\
\text { stages }\end{array}$} & \multirow{2}{*}{$\begin{array}{c}\text { collected } \\
\text { stages }\end{array}$} & \multirow[b]{2}{*}{ volume } & \multirow[b]{2}{*}{ affected functions } & \multirow[b]{2}{*}{ Gene ID/name } & \multicolumn{2}{|c|}{ DEGs trend } & \multirow{2}{*}{$\begin{array}{l}\text { treatment } \\
\text { period (d) }\end{array}$} & \multirow{2}{*}{$\begin{array}{l}\text { sampling } d(d \text { post first day } \\
\text { of treatment) }\end{array}$} & \multirow[b]{2}{*}{ references } \\
\hline & treatment & $\begin{array}{c}\text { raised } \\
\text { environment }\end{array}$ & & & & & & & up & down & & & \\
\hline \multirow{8}{*}{$500 \mathrm{ppb}$} & \multirow{8}{*}{ feeding (water) } & \multirow{8}{*}{ field } & \multirow{8}{*}{ NGS } & \multirow{8}{*}{ larvae } & \multirow{8}{*}{ adults } & \multirow{8}{*}{$1 \mu \mathrm{L}$} & total DEGs & 578 & & & \multirow{8}{*}{4} & \multirow{8}{*}{21} & \multirow{8}{*}{ [66] } \\
\hline & & & & & & & detoxification & 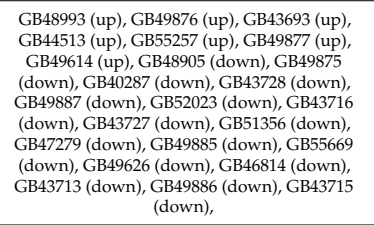 & 7 & 17 & & & \\
\hline & & & & & & & immunity & $\begin{array}{l}\text { GB51223 (down), GB47318 (down), GB47546 } \\
\text { (down), GB40164 (down), GB53576 (down) }\end{array}$ & 0 & 5 & & & \\
\hline & & & & & & & mitochondria & $\begin{array}{l}\text { GB441116 (up), GB425850 (up), GB50970 (up), } \\
\text { GB42141 (up), GB49306 (up), GB46083 (up), } \\
\text { GB53201 (up), GB499942 (down), , BB47970 } \\
\text { (down), GB25250 (down), GB551583 (down) }\end{array}$ & 7 & 4 & & & \\
\hline & & & & & & & metabolism & 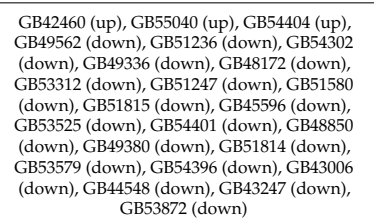 & 3 & 21 & & & \\
\hline & & & & & & & neuron development & 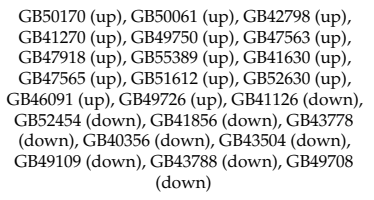 & 4 & 19 & & & \\
\hline & & & & & & & sensory processing & 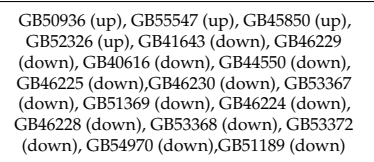 & 4 & 14 & & & \\
\hline & & & & & & & signaling pathway & $\begin{array}{l}\text { GB49937 (up), GB41862 (down), GB50705 } \\
\text { (down), GBp7566 (down), GB479761 (down), } \\
\text { GB48815 (down), GB41220 (down), GB51125 } \\
\text { (down) }\end{array}$ & 2 & 6 & & & \\
\hline
\end{tabular}


Table 2. Cont.

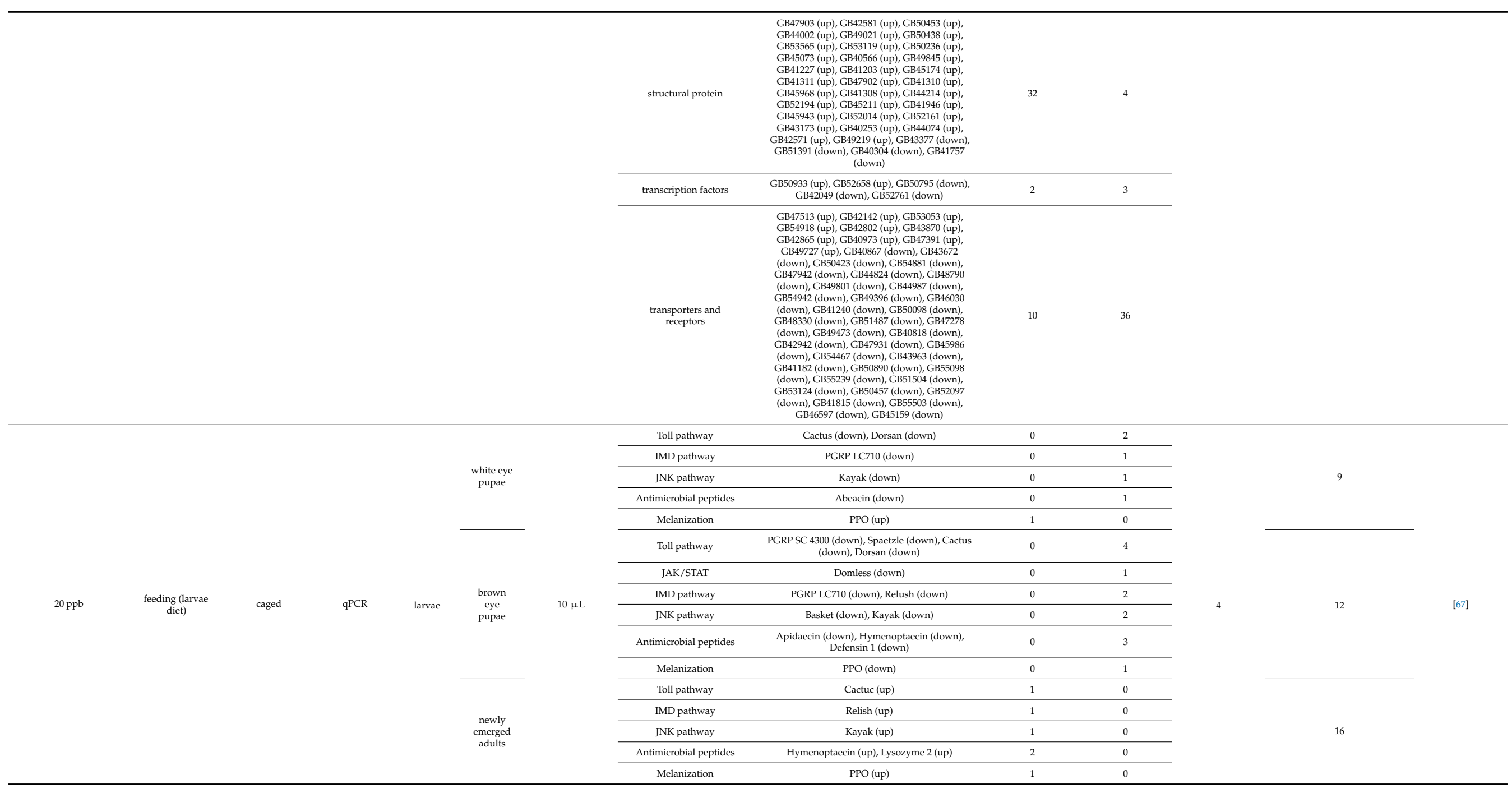


Quantitative PCR can provide accurate and specific expression profiles of target gene sets, but data are limited and restricted to well-understood pathways. The transcriptomic approach is essential and critical to understanding the comprehensive impacts of imidacloprid on honey bees. Wu et al. (2017) used the next-generation sequencing (NGS) approach to profile the transcriptome of nurse bees with imidacloprid exposure [64]. For 8-day-old nurse bees, exposure to $10 \mathrm{ppb}$ imidacloprid for $8 \mathrm{~d}$ resulted in 509 differentially expressed genes, (DEGs), with 160 up- and 349 downregulated genes,. The upregulated genes, were related to the functions of ribosomal proteins (including $1860 \mathrm{~S}$ ribosomal proteins and $1040 \mathrm{~S}$ ribosomal proteins), phototransduction, visual perception, and photoreception. In contrast, the downregulated genes, were related to actin binding, the actin cytoskeleton, muscle attachment, and somatic muscle development. Behavioral observations also confirmed impaired climbing ability [64]. For 11-day-old nurse bees, exposure to $20 \mathrm{ppb}$ imidacloprid for $11 \mathrm{~d}$ resulted in 1 and 130 upregulated and downregulated genes, respectively. GO analysis suggests that the downregulated genes, were related to detoxification response, immunity, and oxidation-reduction [64] (Table 2a).

Although queen bees are not directly in contact with imidacloprid-contaminated sources, they can still be affected through brooding behavior from nurse bees or from wax. Furthermore, imidacloprid can accumulate in royal jelly, while nurse bees consume contaminated pollen [35]. The effect of imidacloprid on queen bees should thus be examined. In a physiological study, exposure to a sublethal dosage of imidacloprid caused a low fecundity rate and delayed egg laying, worker brood care, and production, and reduced the queen survival rate [68,69]. Imidacloprid-treated queens showed less activity and tended to stay immobile, and the effect was dose-dependent [70]. Exposure to $2.5 \mathrm{ppb}$ imidacloprid for 4 continuous $\mathrm{d}$ caused a strong reduction in the standard metabolic rate in queen bees [70]. To confirm the molecular effect, Chaimanee et al. (2016) used qPCR to detect the expression of P450 superfamily genes, immunity, and development/antioxidant enzyme coding after $20 \mathrm{ppb}$ imidacloprid treatment of queen bees with topical treatment during the adult stage. Among the 15 target genes, only CYP4G11 (P450 superfamily) and thioredoxin peroxidase were upregulated, while CYP306A1 (P450 superfamily), CYP6AS14 (P450 superfamily), apidaecin (immunity), eater (immunity), Amel/LRR (immunity), VgMC (immunity), and development and antioxidant enzyme-coding genes, SOD and hexamerin 70b were downregulated [59] (Table 2b).

Exposure to sublethal imidacloprid during the adult stages of both workers and queens has been investigated and described. Immunity, detoxification, and antioxidant responses were of high interest and thus targeted in most reports. Although conditions varied, the expression trends of a large proportion of related genes, were downregulated. Table $2 \mathrm{a}$ shows the concentration/dosage of imidacloprid applied, treatment stages, affected gene lists, and gene regulation trends in honey bees.

\section{The Effects of Sublethal Dosages of Imidacloprid Exposure during the Larval Stage from a Molecular Perspective}

Honey bee larvae are more tolerant to higher concentrations/dosages of imidacloprid than adults, and they can survive treatments and develop into adults [28]. Nevertheless, the larvae showed delay in development. The average eclosion date was 1 to $2 \mathrm{~d}$ delayed compared to the control, and the developed adults showed a short lifespan and low survival rate [71,72]. Full-grown adults showed disorders in olfactory associative learning behavior and a high failure rate in foraging behavior [41,73], and a precocious forager was developed [73,74]. Compared to a fully developed, normal forager, an early matured forager showed poor flying skills and less foraging efficiency, and the death rate was higher [74-78]. A neurological study revealed fewer synapses in the mushroom body than in healthy bees, suggesting that neurological damage occurs from the intake of sublethal dosages of imidacloprid [58]. Molecular effects thus need to be verified. Using the qPCR approach, Tesovnik et al. (2019) examined honey bee adult immune response-related genes, after exposure to $20 \mathrm{ppb}$ imidacloprid during the larval stage for 4 continuous $\mathrm{d}$. They identified the downregulation of immune responses, including Toll, JAK/STAT, IMD, JNK, 
and antimicrobial peptides, in both white-eyed and brown-eyed pupae, while those of adults were upregulated [67] (Table 2c).

Using a transcriptomic approach, Wu et al. (2017) revealed the effects on adult workers after exposure to sublethal imidacloprid treatment during their larval stage [66]. Exposure to $500 \mathrm{ppb}$ imidacloprid for 4 continuous d during the larval stage induced 578 differentially expressed genes, in 5/6-day-old adults. Among them, 329 genes, were annotated and classified into 11 functional groups, while the functions of the remaining 249 genes, required further research [66]. The 11 groups were detoxification (24 genes, 7 upregulated, 14 downregulated), immunity (5 genes, all downregulated), mitochondria (11 genes, 7 upregulated, 4 downregulated), metabolism (24 genes, 3 upregulated, 21 downregulated), neuron development (23 genes, 4 upregulated, 19 downregulated), sensory processing (18 genes, 4 upregulated, 14 downregulated), signaling pathways (8 genes, 2 upregulated, 6 downregulated), structural proteins (36 genes, 32 upregulated, 4 downregulated), transcription factors (5 genes, 2 upregulated, 3 downregulated), transporters and receptors (46 genes, 10 upregulated, 36 downregulated), and others (129 genes,) (Table 2c). Furthermore, the expression level of genes, encoding major royal jelly proteins (MRJPs) was significantly downregulated, suggesting that the composition of royal jelly may be affected and that malnutrition may occur for queen and young larvae [66].

To comprehensively evaluate the molecular effects of imidacloprid on worker development, transcriptomes of 9-day-old larvae and 0-, 7-, 14-, and 20-day-old adults were sequenced after exposure to $1 \mu \mathrm{L}$ of $1 \mathrm{ppb}, 10 \mathrm{ppb}$, or $50 \mathrm{ppb}$ imidacloprid during the larval stage for 4 consecutive d (2-day-old to 5-day-old larvae) [79]. The numbers of DEGs and the developmental queue showed no significant correlation, and a dosage-dependent effect was observed only on 9-day-old larvae and 0-day-old adults. In 7-day-old adults, DEGs were only identified in bees with $10 \mathrm{ppb}$ treatment during the larval stage, and more than $80 \%$ of them were upregulated. The number of DEGs decreased as worker development progressed but then peaked in 14-day-old adults. The DEG numbers were 4871, 5863, and 5848 for the 1,10, and $50 \mathrm{ppb}$ imidacloprid treatments, respectively. Very few DEGs were identified in 20-day-old adults for all treatments. Further comparisons were performed and revealed high transcriptome similarity between 14-day-old imidacloprid-treated bees and 20-day-old controls. The upregulation of forager regulators, transcription factors that regulate the honey bee behavioral state from nurse to forager, was also identified, suggesting that precocious foragers may develop when exposed to sublethal concentrations of imidacloprid during the larval stage. Common effects among workers of different ages were then investigated by comparing the population of DEGs. As very few DEGs were identified from imidacloprid-treated 20-day-old adults, the shared DEGs were analyzed among 9-day-old larvae and 0-, 7-, and 14-day-old adults. A total of 35 genes, were found to be constantly differentially expressed. Two of them were related to the nervous system, including neuroactive ligand receptor (GB40975) and nicotinamide riboside kinase (GB53410). Nicotinamide riboside kinase (Nrk1) can protect damaged neurons from degradation, and its expression is especially induced in the presence of nerve damage [80]. The constant upregulation of Nrk1 confirmed damage to the honey bee neural system after imidacloprid treatment during the larval stage. To understand the effect of imidacloprid on workers of different ages, we will focus on the affected GO terms and pathways at different ages in the following section.

\section{The Affected Molecular Pathways at Different Ages of Honey Bee Workers}

The numbers of DEGs varied among different ages and treatments, without any significant trend. To further understand the function of affected genes, GO analysis and KEGG pathway prediction were performed for DEGs identified at various worker ages. For 9-dayold larvae, upregulated DEGs were significantly enriched in biological terms of translation

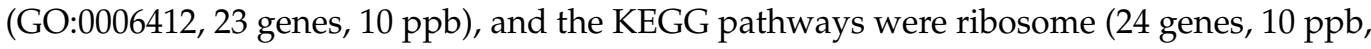
ame03010) and proteasome (6 genes, $10 \mathrm{ppb}$, ame03050). For downregulated genes, DEGs were significantly enriched in biological terms of homophilic cell adhesion via plasma 
membrane adhesion molecules (GO:0007156, 5 genes, $10 \mathrm{ppb}$ ) and regulation of Rho protein signal transduction (GO:0035023, 5 genes, $10 \mathrm{ppb}$ ). The KEGG pathway was enriched in the Hippo signaling pathway-fly (ame04391, 8 genes, $10 \mathrm{ppb}$ ) and insulin resistance (ame04931, 7 genes, $10 \mathrm{ppb}$ ). For 0-day-old adults, upregulated DEGs were enriched in biological terms of regulation of transcription, DNA-templated (GO:0006355, 16 genes, $50 \mathrm{ppb}$ ) and signal transduction (GO:0007165, 7, 11, and 13 genes, for 1, 10, and $50 \mathrm{ppb}$, respectively), while no significant KEGG pathway was identified. For downregulated DEGs, no significant biological term was identified, and the KEGG pathways were enriched in oxidative phosphorylation (ame00190, 14 genes, $50 \mathrm{ppb}$ ) and carbon metabolism (ame01200, 17 genes, $50 \mathrm{ppb}$ ). For 7-day-old adults, upregulated DEGs were enriched in translation (GO:0006412, 14 genes, $10 \mathrm{ppb}$ ) and ribosome (KEGG pathway ame03010, 18 genes, $10 \mathrm{ppb}$ ). In contrast, the downregulated DEGs were enriched in terms related to the regulation of transcription, DNA-templated (GO:0006355, 5 genes, 10 ppb). For 14-day-old adults, more than 4000 DEGs were identified from all treatments; thus, more significant functions/pathways were identified. For upregulated DEGs, biological terms were enriched in transcription, DNA-templated (GO:0006351, 38 genes, $10 \mathrm{ppb}$ ) and translation (GO:0006412, 40 genes, $50 \mathrm{ppb}$ ), and the KEGG pathways were ribosome (ame03010, 48 genes, $10 \mathrm{ppb}$ ), FoxO signaling pathway (ame04068, 25 and 27 genes, for 10 and $50 \mathrm{ppb}$, respectively), mTOR signaling pathway (ame04150, 16 genes, $50 \mathrm{ppb}$ ), Hippo signaling pathway-fly (ame04391, 26 and 24 genes, for 10 and $50 \mathrm{ppb}$, respectively), phototransduction-fly (ame04745, 14 genes, for both 1 and $50 \mathrm{ppb}$ ), and insulin resistance (ame04931, 21 and 22 genes, for 10 and $50 \mathrm{ppb}$, respectively). For downregulated DEGs, only tRNA processing (GO:0008033, 9 genes, $50 \mathrm{ppb}$ ) was significantly enriched in GO analysis, and the KEGG pathways were Fanconi anemia pathway (ame03460, 15 genes, 50 ppb), fatty acid degradation (ame00071, 13 genes, $50 \mathrm{ppb}$ ), fatty acid elongation (ame00062, 9 genes, $1 \mathrm{ppb}$ ), fatty acid metabolism (ame01212, 17 genes, 1ppb), and metabolic pathways (ame01100, 172 genes, 1 ppb). Upregulation of the Hippo signaling pathway, mTOR signaling pathway, and phototransduction was observed in 14-day-old adults. The Hippo signaling pathway and mTOR signaling pathway are involved in the control of cell proliferation, growth and development [81,82], while phototransduction is the process that converts photons into an action potential in photoreceptor cells (https:/ / www.genome.jp/dbget-bin/www_bget?ame04745; accessed on 29 October 2021).

For 9-day-old larvae, the physiological responses of up-regulated DEGs were unclear, but the down-regulation of Hippo signaling pathway may suggest a defect or delay of development [81]. For 0- and 7-day-old adults, most of the DEGs were enriched in terms involved in multiple functions or fundamental pathways, such as transcription and translation. We did not observe terms related to any physiological response, suggesting that the effect on imidacloprid might not reach the threshold of damaging the downstream pathways or resulting in severe physiological effect. For 14-day-old adults, the upregulation of development-related pathways may be related to a maturation process of individuals, while the downregulation of metabolism pathways and fatty acid metabolism may suggest a defect of metabolism or energy storage, especially of fatty acid. Workers suffering a shortage of energy sources or metabolic disorder may be under stress and have shorter life spans [83]. In addition, the DNA repairing process may also be affected, as the Fanconi anemia pathway, the DNA repairing pathway [84], was found to be downregulated. These differentially expressed terms/pathways may be correlated with imidacloprid treatment during the larval stage, as some of them showed related general functions. Nevertheless, they may also be correlated with the developmental queue of honey bees. The transcriptomic profiles suggested the development of precocious foragers in 14-day-old adults after imidacloprid treatment during the larval stage. The switch from nurse bees to foragers may involve many physiological changes in tissues/organs, and foragers are more positively phototactic $[79,85]$. Thus, at least three pathways were correlated with the development of honey bees. Either hypothesis or both are possible, as the precocious event is also induced by imidacloprid treatment. The affected GO terms, KEGG pathways, and gene lists after 
different concentrations of imidacloprid treatments are shown in Supplementary Table S1 (upregulated genes, in 9-day-old larvae), 2 (downregulated genes, in 9-day-old larvae), 3 (upregulated genes, in 0-day-old adults), 4 (downregulated genes, in 0-day-old adults), 5 (upregulated genes, in 7-day-old adults), 6 (downregulated genes, in 7-day-old adults), 7 (upregulated genes, in 14-day-old adults), and 8 (downregulated genes, in 14-day-old adults).

To understand the significance and network connection of differentially expressed terms/pathways, overrepresentation analysis was performed for GO biological pathways of upregulated and downregulated DEGs for 9-day-old larvae and 0-, 7-, and 14-day-old adults among different concentrations of imidacloprid treatments (Figure 1a,b). For 9-dayold larvae, upregulated DEGs were enriched in the structural constituents of the ribosome and transmembrane transporter activity among different concentrations of imidacloprid treatment, while those of $0-, 7-$, and 14-day-old adults were voltage-gated ion channel activity (0-day), structural molecule activity (7-day), structural constituent of ribosome (7-and 14-day), and helicase activity (7-day) (Figure 1a). Downregulated DEGs enriched in 9-day-old larvae were related to guanyl-nucleotide exchange factor activity, protein kinase activity, calcium ion binding, and protein serine/threonine kinase activity, while those of $0-, 7-$, and 14-day-old adults were enriched in oxidoreductase activity (0-day), sequencespecific DNA binding (7-day), structural constituent of the cuticle (7-day), nuclease activity (14-day), and isomerase activity (14-day) (Figure 1b). The top 10 enriched GO pathways are shown in Supplementary Figure S1a (upregulated),b (downregulated).

a

9-days-old larvae

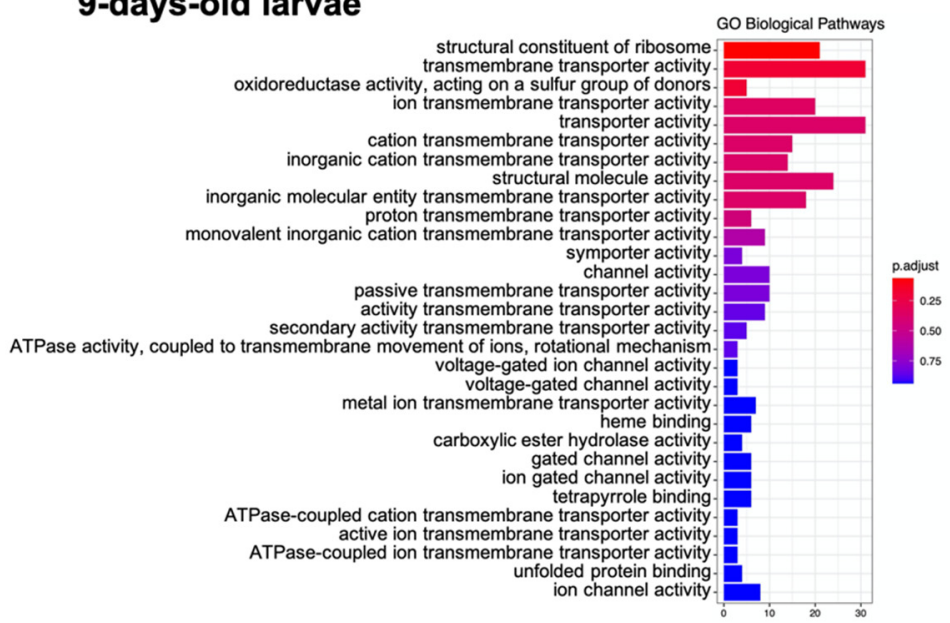

\section{0-day-old adults}

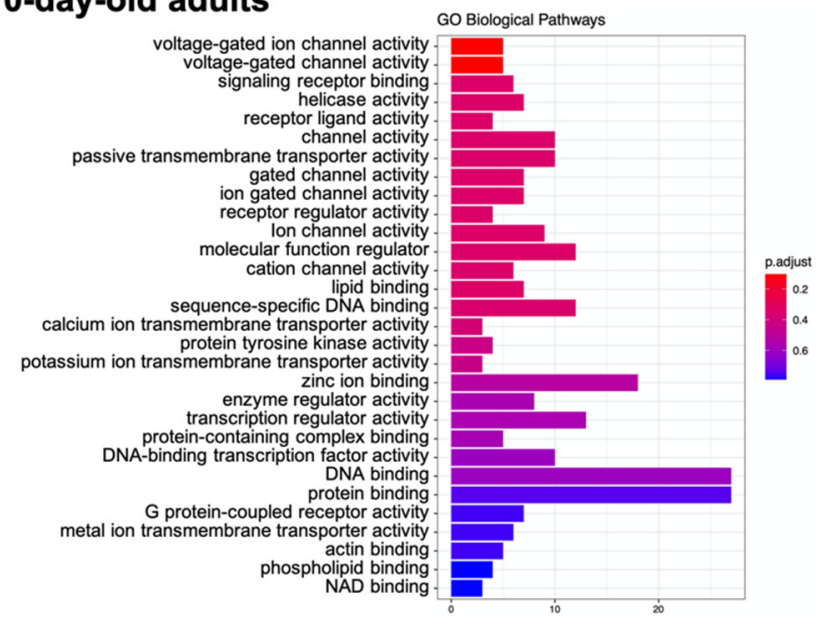

14-days-old adults

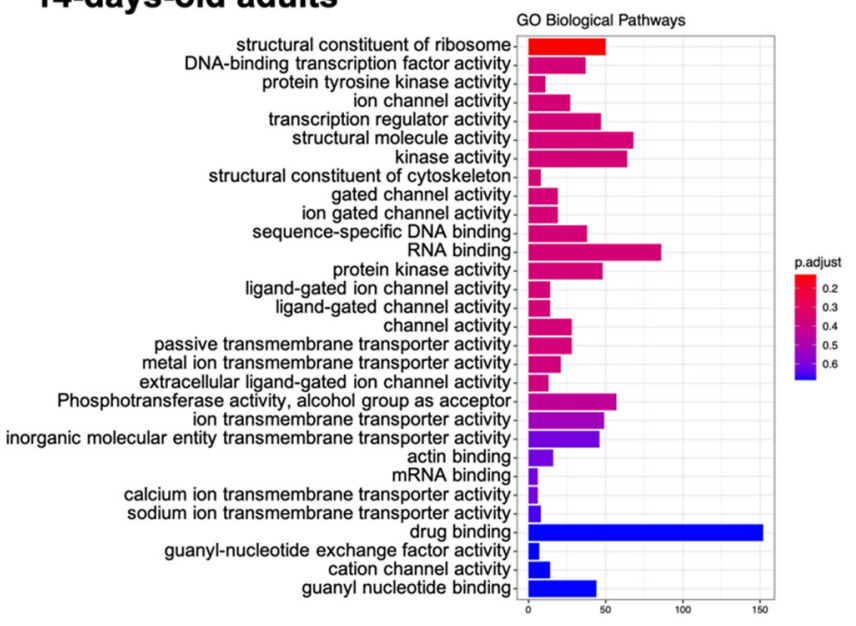

\section{7-days-old adults}

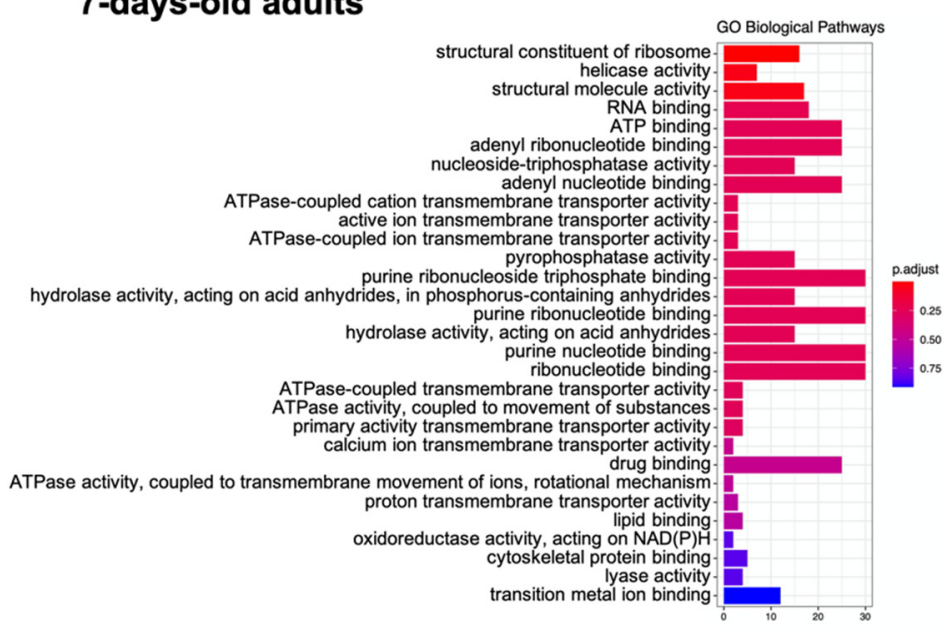

Figure 1. Cont. 
b

9-days-old larvae

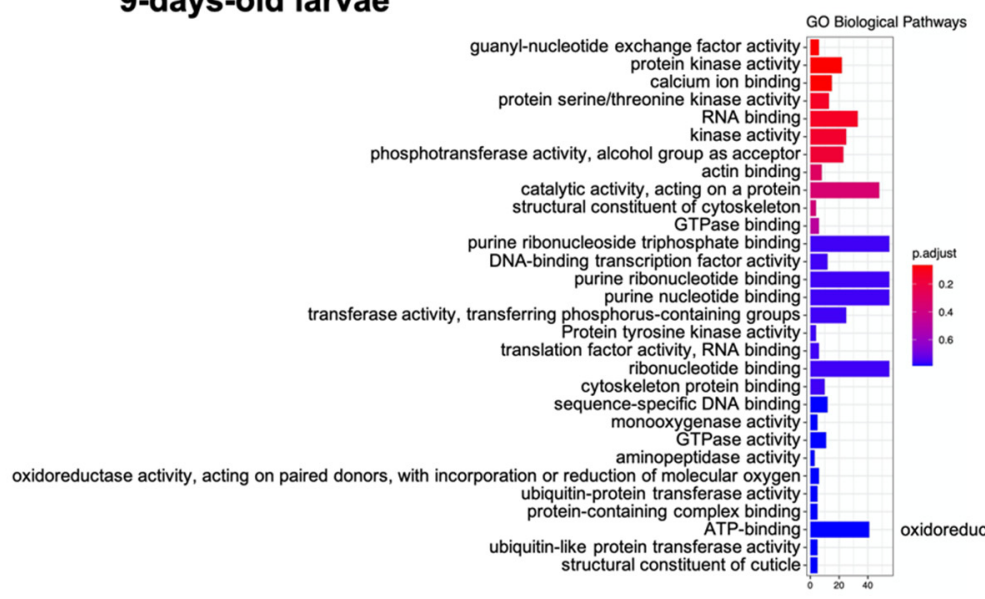

0-day-old adults

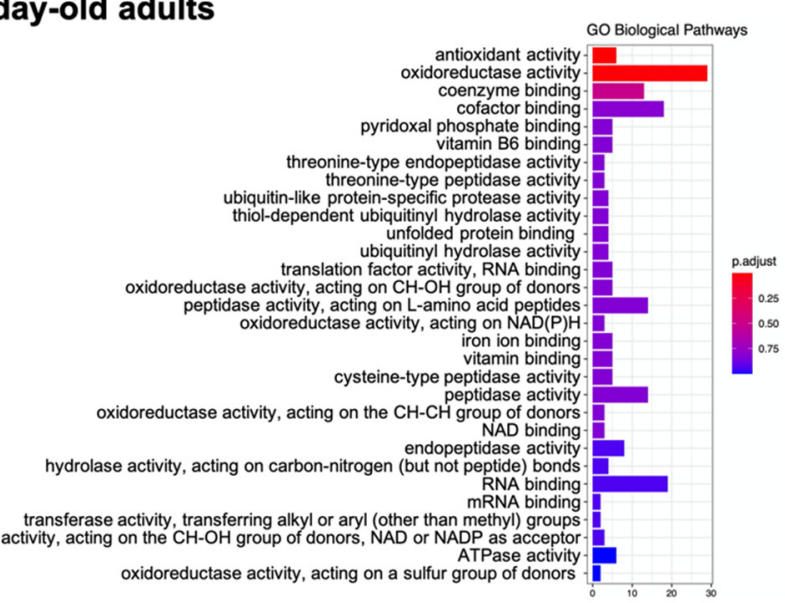

7-days-old adults

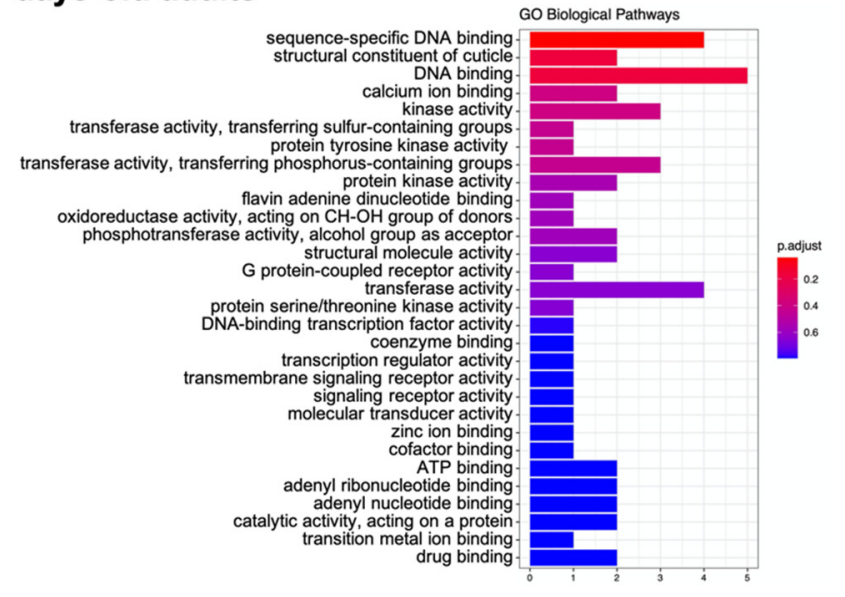

14-days-old adults

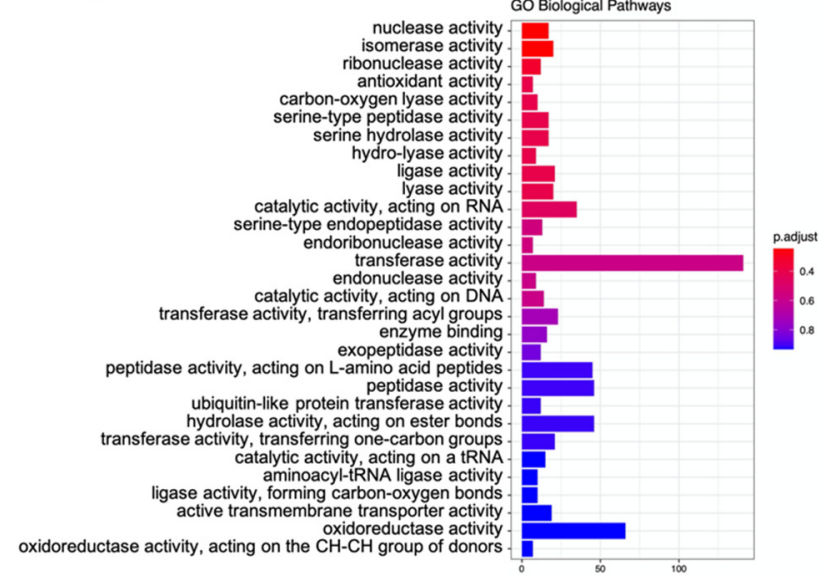

Figure 1. GO biological pathways of (a) upregulated and (b) downregulated DEGs among different imidacloprid treatments of 9-day-old larvae, 0 -day-old adults, 7-day-old adults, and 14-day-old adults. $X$-axis: number of genes,; $Y$-axis: GO terms; p.adjust: the adjusted $\mathrm{p}$ value of identified GO terms; bar color from red to blue represents the adjusted $\mathrm{p}$ value from low to high.

To provide better insights into how those DEGs are involved in significant terms, considering the potential biological complexities in which a gene may belong to multiple annotation categories, to provide information on numeric changes if available, and to better analyze the missing/gaining pathway functions, further analysis was performed. We provided centplots (Figure 2a,b) $[86,87]$ to extract the complex association, which depicts the linkages of genes, and biological concepts as a network. Although the quantity of DEGs identified in 0-day-old adults was nearly the same as those identified in 9-day-old larvae and greater than those identified in 7-day-old adults, the gene set size of 0-day-old adults in the upregulated group was significantly smaller in the representative pathways compared to $9 \mathrm{~d}$ larvae and $7 \mathrm{~d}$ and $14 \mathrm{~d}$ adults (Figure $2 \mathrm{a}$ ). The gene set size corresponding to the enriched pathways and thus the DEGs in 0-day-old adults were enrolled in related, simple, and few functional pathways compared to 9-day-old larvae and 7-day-old adults. This may be correlated with the task performance status of the worker, as 0-day-old workers participate only in simple tasks [88], or the effect of imidacloprid was diminished during the process of metamorphosis. In addition, we observed that the downregulated DEGs of 0-day-old adults lacked oxidoreductase activity (GO:0016491) but recovered in 14-day-old adults. Oxidoreductase activity (GO:0016491) is an important biochemical reaction that catalyzes the transfer of electrons from one molecule to another, suggesting that high electron transfer activity was required for 14-day-old adults. For downregulated DEGs in 
7-day-old adults, we also found downregulation of the structural constituent of the cuticle. Exposure to 5 or $200 \mathrm{ppb}$ imidacloprid affected the cuticle proteolysis of honey bees, and the effect was cast-dependent [89]. The downregulation of cuticle constituents is highly likely to be correlated with the affected cuticle proteolysis. Some unknown structural reconstitution or regeneration may occur in 7-day-old adults, and the process would be hampered due to structural defects.

a

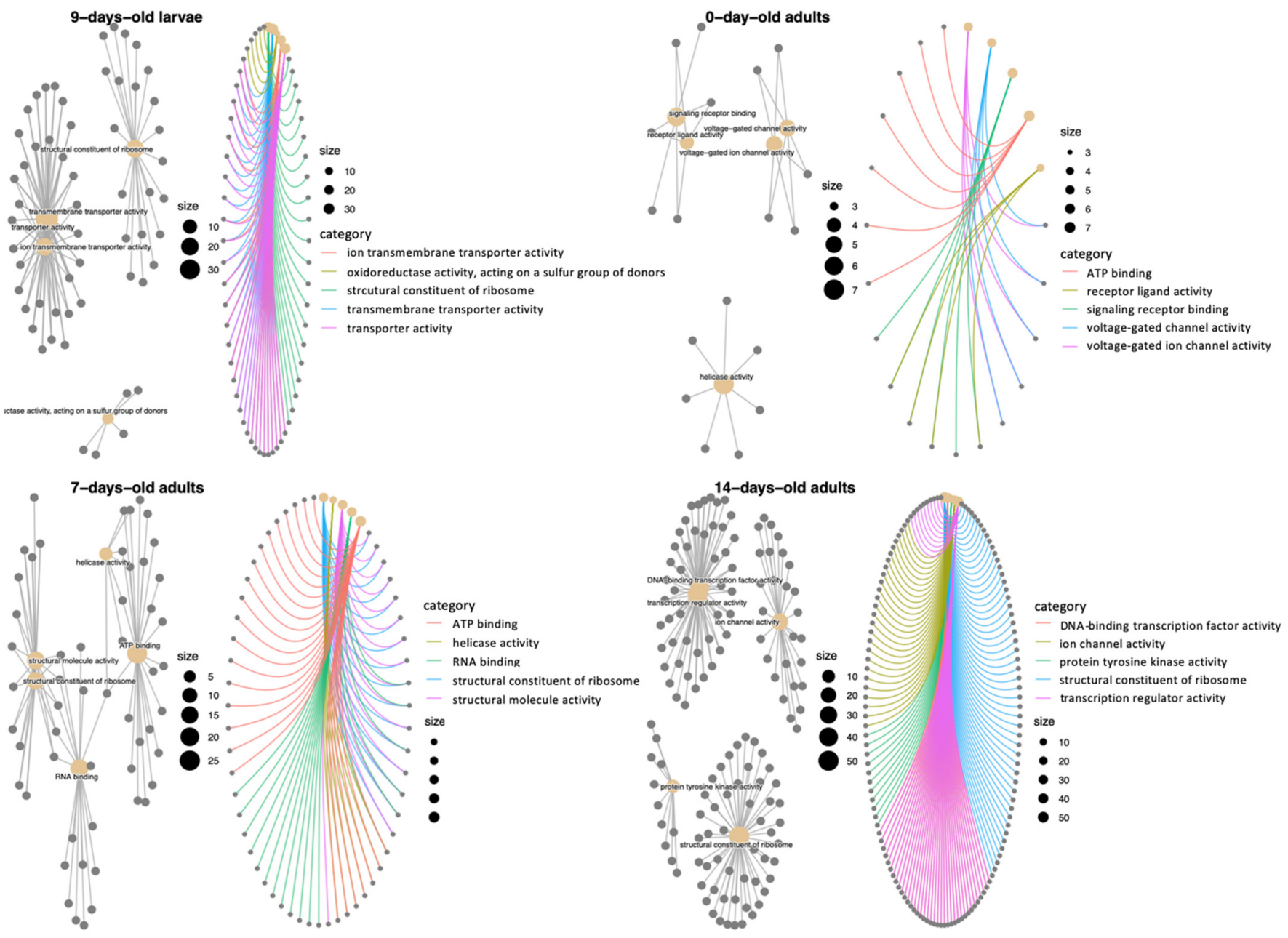

Figure 2. Cont. 
b
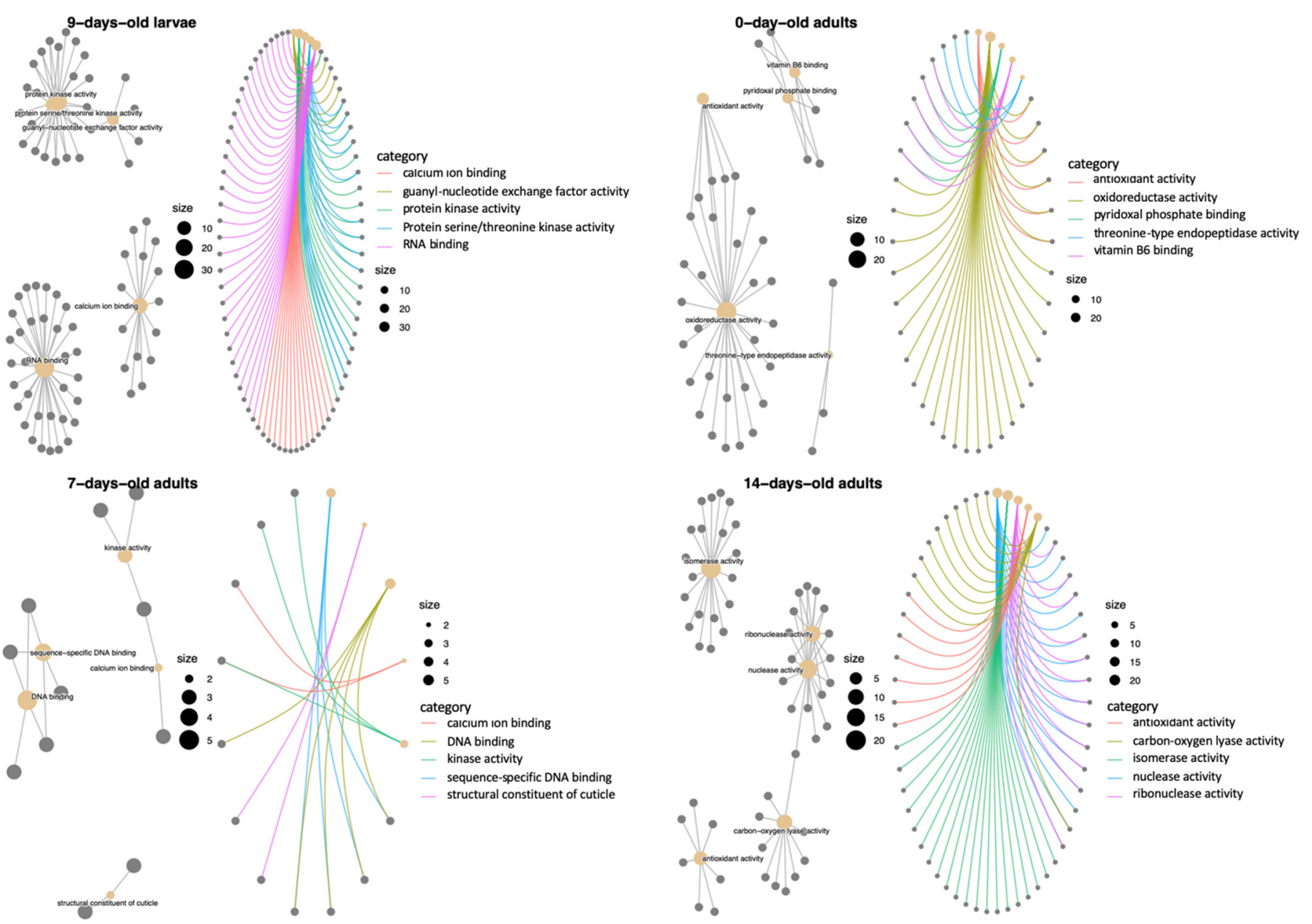

Figure 2. Gene-pathway concept network for overrepresentation testing for GO terms in the pool of (a). upregulated and (b). downregulated DEGs among different imidacloprid treatments in 9-day-old larvae, 0-day-old adults, 7-day-old adults, and 14-day-old adults. Size: number of DEGs; category: the GO terms category. Gray lines indicate the network connection, and the weight of the line reflects the degree of connection between terms. Colored lines indicate the connection between terms and the involved genes,. The concept network plot shows that the genes, are involved in significant terms and biological complexness.

GO enrichment networks organized on the basis of connecting overlapping gene sets were predicted for DEGs identified at different worker ages. For upregulated DEGs of 9-day-old larvae, most of the functional terms were connected, and networks correlated with terms of ion transmembrane transporter activity and ion transmembrane activity. For 0-, 7-, and 14-day-old adults, the network connections for different adult ages were tightly coordinated with ion channel activity (0-day-old), signaling/enzyme receptor (0-day-old), voltage-gated ion channel activity (0-day-old), ribonucleotide binding (7-day-old), ATPbinding/ATPase-coupled transmembrane transporter activity (7-day-old), helicase activity (7-day-old), ion/membrane transporter activity (14-day-old), and gated channel activity (14-day-old) (Figure 3a). There were some insignificant and isolated terms, such as NAD binding (0-day-old), cytoskeletal protein binding (7-day-old), lyase activity (7-day-old), actin-binding (14-day-old), and mRNA binding (14-day-old). For downregulated DEGs, the network connections among all GO terms were not as highly connected as those among upregulated DEGs. For 9-day-old larvae, the GO terms catalytic activity, protein kinase activity, and ribonucleotide binding showed complex connections. For different adult ages, the GO terms of peptidase activity (0-day-old), unfolded protein binding (0-day-old), 
transferase activity (7-day-old), drug binding (7-day-old), catalytic activity (7-day-old), protein kinase activity (7-day-old), phosphotransferase activity, alcohol group as receptor (7-day-old), catalytic activity (acting on RNA) (14-day-old), and nuclease activity (14-dayold) showed complex connections with other terms (Figure $3 b$ ). Supplementary Figure S2a,b illustrate the GO term networks with directional connections for upregulated and downregulated DEGs, respectively.

a

\section{9-days-old larvae}

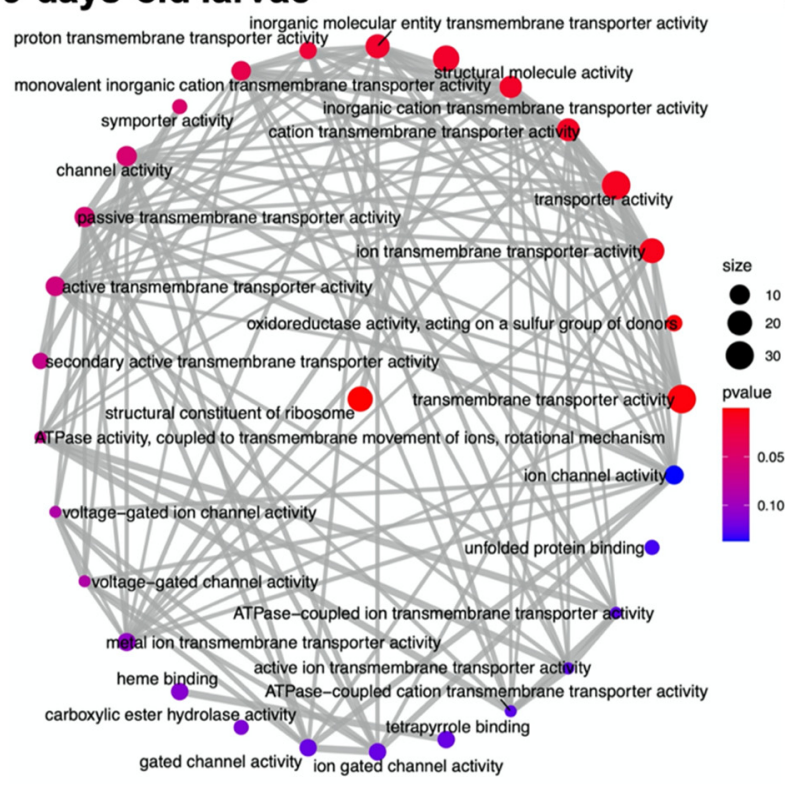

\section{7-days-old adults}

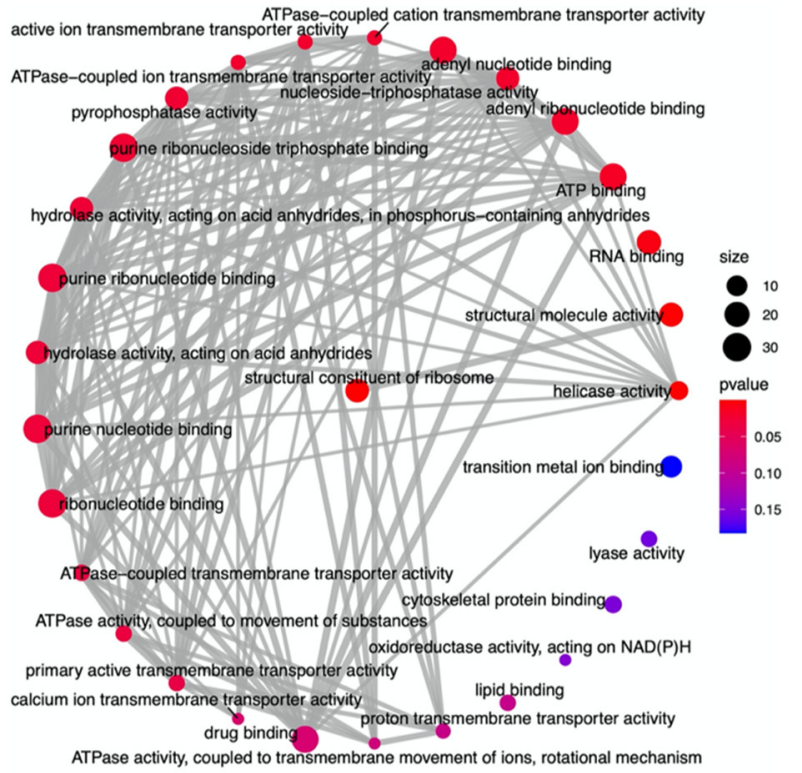

\section{0-day-old adults}

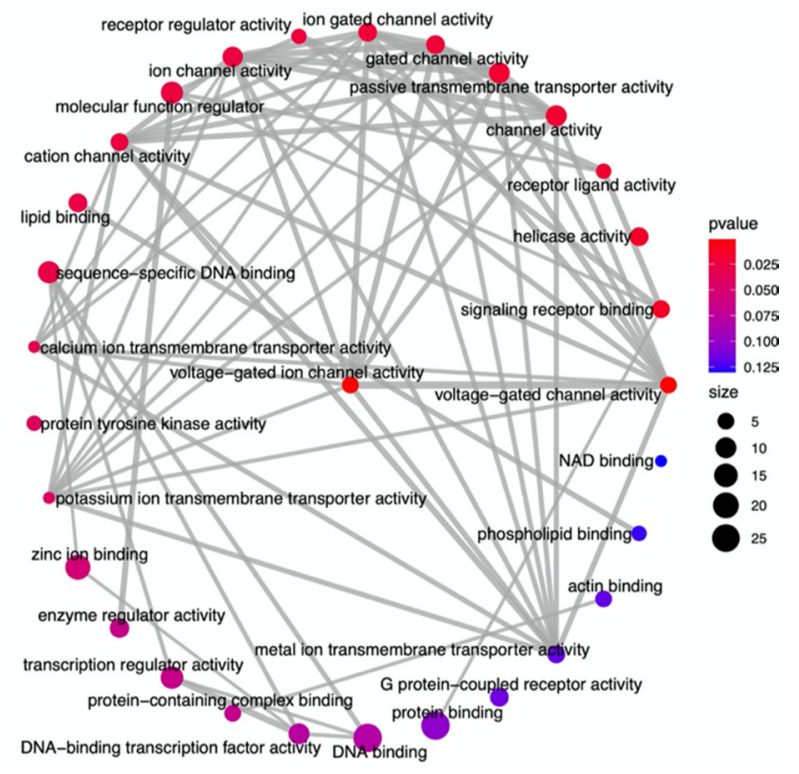

14-days-old adults

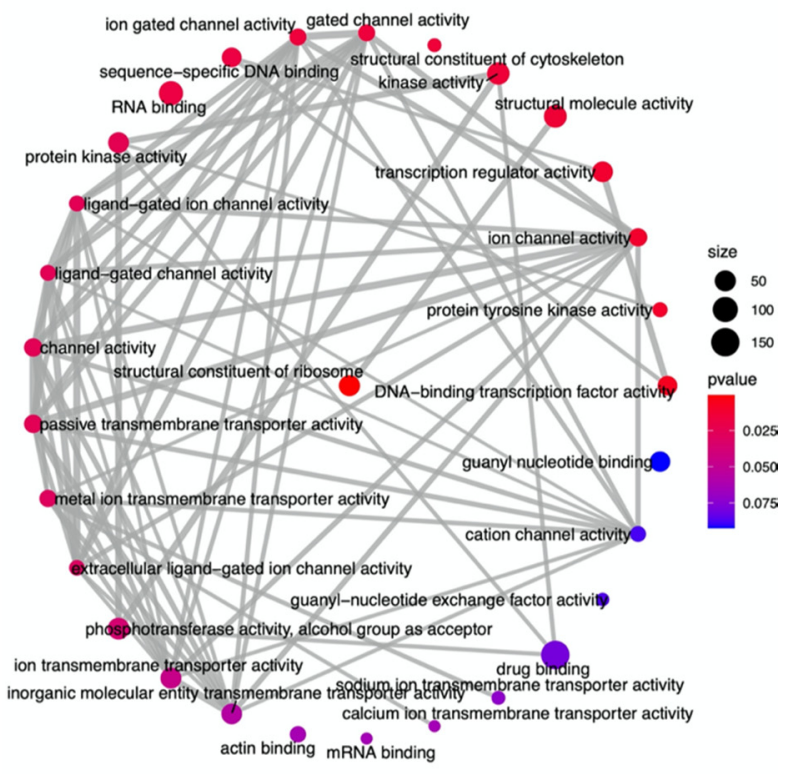

Figure 3. Cont. 
b

\section{9-days-old larvae}

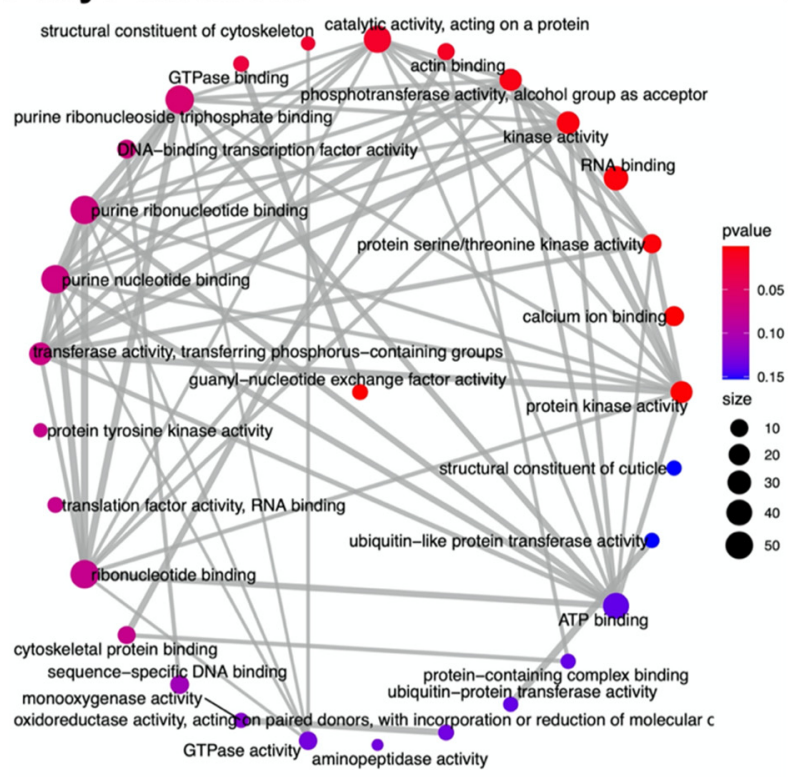

\section{0-day-old adults}

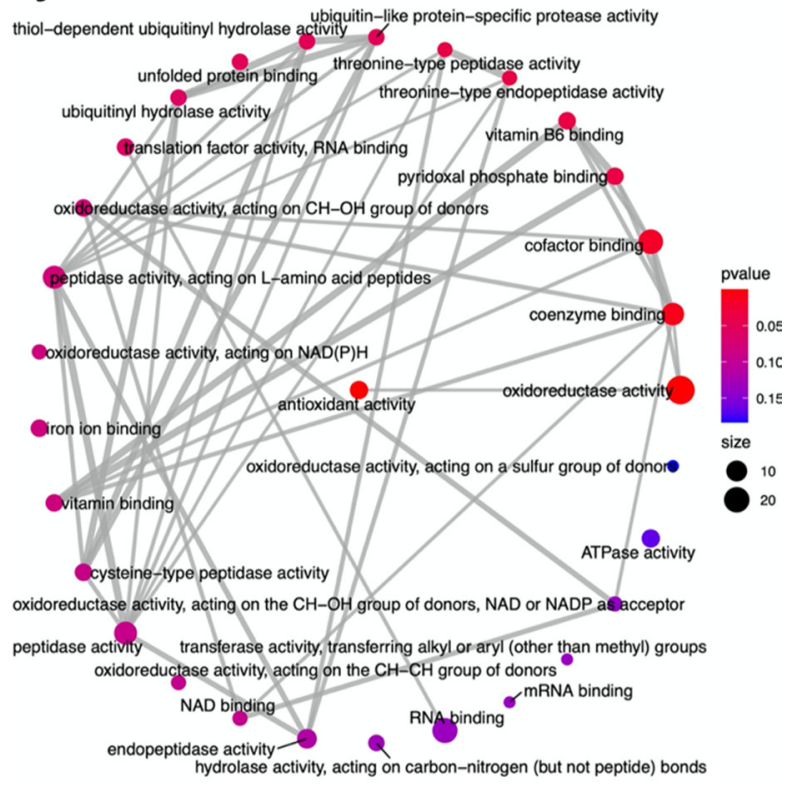

14-days-old adults

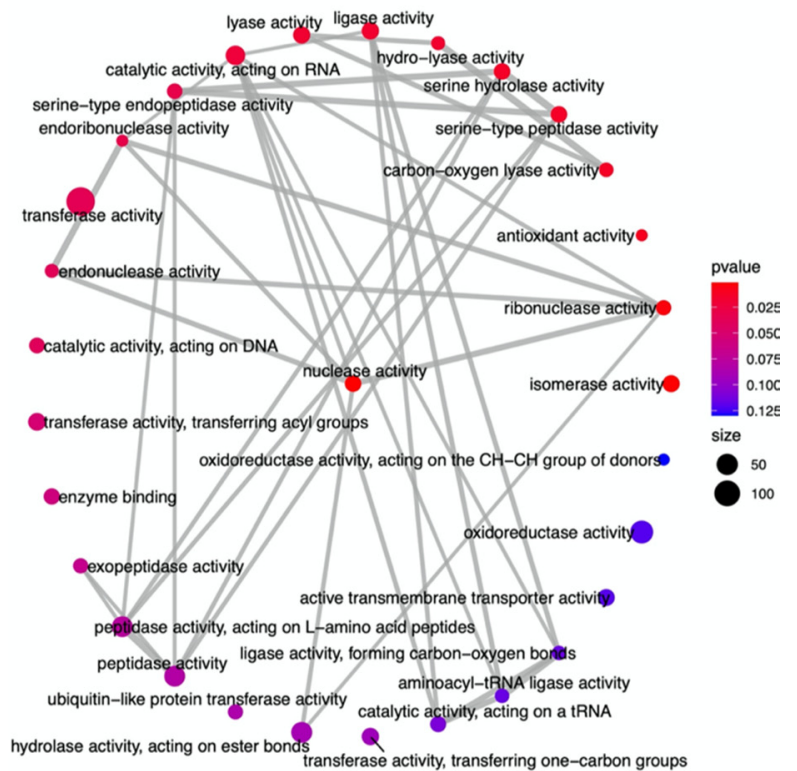

Figure 3. Enrichment maps for overrepresentation testing for GO terms in the pool of (a) upregulated and (b) downregulated DEGs among different imidacloprid treatments in 9-day-old larvae, 0-day-old adults, 7-day-old adults, and 14-day-old adults. Size: number of DEGs; $p$ value: the $p$ value of identified GO terms. The color from red to blue represents the $p$ value from low to high. Gray lines indicate the network connection, and the weight of the line reflects the degree of connection between terms.

After exposure to $500 \mathrm{ppb}$ imidacloprid during the larval stage, developed adults showed a substantial impact on the expression of detoxification, metabolism, neuron development, structural protein, and transporters and receptors [66]. While providing $20 \mathrm{ppb}$ imidacloprid during the larval stage, immune pathway-related genes, were significantly downregulated in pupae and newly emerged adults [67]. From the perspective of the developmental queue, the affected genes, and functional pathways were diverse among workers 
of different ages. Nevertheless, they seemed to be coordinated with bee development and task performance and may consequently result in precocious foragers [79].

\section{The Molecular Effect of Imidacloprid on Other Pollinators}

Imidacloprid affects other pollinator bees, in addition to honey bees. Bumble bees seem to be very sensitive to imidacloprid. Ten ppb imidacloprid caused reductions in foraging activity, locomotion, and even foraging rhythmicity in Bombus terrestris [90,91]. Exposure to $7.5 \mathrm{ppb}$ imidacloprid for 4 continuous $\mathrm{d}$ resulted in a weak influence. Only 1 gene was differentially expressed, 1 gene showed alternative splicing in bumble bee workers, and 8 genes, had alternative splicing in queen bumble bees [90]. Bebane et al. profiled the methylome and transcriptome of bumble bee (B. terrestris) workers after exposure to realistic field imidacloprid concentrations (10 ppb) for $6 \mathrm{~d}$. A total of 405 genes, were differentially expressed (192 upregulated, 213 downregulated), while there was no significant effect on DNA methylation. DEGs were enriched in functional terms related to apoptotic processes (33 genes,), energy reserve metabolism (6 genes,), immune response (3 genes,), negative regulation of cell communication (24 genes,), oxidation-reduction process (37 genes,), and P450 genes, (4 genes,), as well as synaptic transmission, xenobiotic metabolism, and resistance to insecticides (28 genes,) [91]. A transcriptomic approach of the Asian honey bee Apis cerana revealed that consuming a sucrose solution containing LC5 (0.968 ppm) of imidacloprid for $24 \mathrm{~h}$ resulted in 709 DEGs among 1-, 8-, and 16-h-post treatments. The upregulation of genes, was related to responses to stimuli, localization, transporter activity, and signal transducer activity, while downregulated genes, were enriched in terms related to metabolic process, detoxification (cytochrome P450), catalytic activity, and structural molecule activity. Additionally, a KEGG analysis suggested the upregulation of the phenylalanine metabolism pathway, FoxO signaling pathway, mTOR signaling pathway, and tyrosine metabolism pathway. Downregulated pathways after imidacloprid exposure were protein processing in the endoplasmic reticulum, arginine and proline metabolism, and glycine, serine, and threonine metabolism [92]. Most of the studies focused on the effects on eusocial bees; very few reported the effect on solitary bees, especially the molecular effect. As the model species for the study of solitary bees, the red mason bee, Osmia bicornis, was found to be very sensitive to imidacloprid [93]. Beadle et al., (2019) sequenced the genome of O. bicornis and confirmed that O. bicornis lacks the superfamily of P450 enzyme but contains a P450 within the CYP9BU superfamily [93]. This enzyme metabolizes thiacloprid but not imidacloprid. O. bicornis is thus thought to be highly sensitive to imidacloprid and can be killed with a relatively low dosage $\left(\mathrm{LD}_{50}\right.$ $0.046 \mu \mathrm{g} / \mathrm{bee})$. Exposure to $0.0001 \mu \mathrm{g}$ of imidacloprid resulted in a total of 27 genes, that were upregulated, while 52 genes, were downregulated. There was no P450 related gene identified after imidacloprid treatment; however, the authors suggest that constitutive rather than changed P450 expression levels were more important for the detoxification process after pesticide exposure [93]. Several affected molecular pathways, such as metabolism, immune response, and detoxification/P450, are found in western honey bees, Asian honey bees, and bumble bees. Although responses vary among different species of insects, a universal effect can still be established on the basis of current understanding.

\section{Conclusions}

In conclusion, the lethal dose/concentration and molecular effects of sublethal dosages of imidacloprid on honey bees and other pollinator bees were integrated and reviewed. Molecular evidence suggests that the expression of the immune response, detoxification, oxidation-reduction, and other development-related genes, was ubiquitously affected among different species of target bees. Transcriptomic approaches revealed that even very low dosages/concentrations of imidacloprid could cause global effects, even altering the developmental queue and inducing a precocious forager. Realistic field levels of imidacloprid severely impact the sustainable development and population dynamics of 
domesticated and wild pollinators. The application of imidacloprid and other neonicotinoid pesticides should be more carefully and rigorously evaluated.

Supplementary Materials: The following are available online at https:/ / www.mdpi.com/article/10 $.3390 /$ ijms222111835/s1.

Author Contributions: Conceptualization: E.-C.Y. and Y.-R.C.; methodology: E.-C.Y., Y.-R.C. and D.T.W.T.; software: ClusterProfiler; GO-term enrichment analysis: D.T.W.T.; writing-original draft preparation, Y.-R.C.; writing-review and editing, E.-C.Y., Y.-R.C. and D.T.W.T.; visualization, D.T.W.T.; supervision, E.-C.Y. All authors have read and agreed to the published version of the manuscript.

Funding: This work was supported by grants from the Ministry of Science and Technology, Taiwan. 110-2313-B-002-035- and 110-2313-B-002-022-MY3; 110-2811-B-002-590-, Postdoc funding to Yun-Ru Chen.

Data Availability Statement: Honey bee RNA-seq raw reads are available at https:/ /www.ncbi.nlm. nih.gov/sra/PRJNA521949 accessed on 27 October 2021.

Conflicts of Interest: The authors declare no conflict of interests.

\section{References}

1. Schmuck, R. No causal relationship between Gaucho ${ }^{\circledR}$ seed dressing in sunflowers and the French bee syndrome. Pflanzenschutz Nachr. Bayer 1999, 52, 257-299.

2. Schmuck, R.; Schöning, R.; Stork, A.; Schramel, O. Risk posed to honeybees (Apis mellifera L., Hymenoptera) by an imidacloprid seed dressing of sunflowers. Pest Manag. Sci. 2001, 57, 225-238. [CrossRef]

3. Jeschke, P.; Nauen, R.; Schindler, M.; Elbert, A. Overview of the status and global strategy for neonicotinoids. J. Agric. Food Chem. 2011, 59, 2897-2908. [CrossRef]

4. Bonmatin, J.-M.; Giorio, C.; Girolami, V.; Goulson, D.; Kreutzweiser, D.P.; Krupke, C.; Liess, M.; Long, E.; Marzaro, M.; Mitchell, E.A.D.; et al. Environmental fate and exposure; neonicotinoids and fipronil. Environ. Sci. Pollut. Res. 2015, 22, 35-67. [CrossRef]

5. Buckingham, S.; Lapied, B.; Corronc, H.; Sattelle, F. Imidacloprid actions on insect neuronal acetylcholine receptors. J. Exp. Biol. 1997, 200, 2685-2692. [CrossRef] [PubMed]

6. Matsuda, K.; Buckingham, S.D.; Kleier, D.; Rauh, J.J.; Grauso, M.; Sattelle, D.B. Neonicotinoids: Insecticides acting on insect nicotinic acetylcholine receptors. Trends Pharmacol. Sci. 2001, 22, 573-580. [CrossRef]

7. Matsuda, K.; Shimomura, M.; Ihara, M.; Akamatsu, M.; Sattelle, D.B. Neonicotinoids show selective and diverse actions on their nicotinic receptor targets: Electrophysiology, molecular biology, and receptor modeling studies. Biosci. Biotechnol. Biochem. 2005, 69, 1442-1452. [CrossRef] [PubMed]

8. Gill, R.J.; Ramos-Rodriguez, O.; Raine, N.E. Combined pesticide exposure severely affects individual- and colony-level traits in bees. Nature 2012, 491, 105-108. [CrossRef] [PubMed]

9. Goulson, D. Review: An overview of the environmental risks posed by neonicotinoid insecticides. J. Appl. Ecol. 2013, 50, 977-987. [CrossRef]

10. Lu, C.; Warchol, K.M.; Callahan, R.A. Sub-lethal exposure to neonicotinoids impaired honey bees winterization before proceeding to colony collapse disorder. Bull. Insectol. 2014, 67, 125-130.

11. Sandrock, C.; Tanadini, M.; Tanadini, L.G.; Fauser-Misslin, A.; Potts, S.G.; Neumann, P. Impact of chronic neonicotinoid exposure on honeybee colony performance and queen supersedure. PLoS ONE 2014, 9, e103592. [CrossRef] [PubMed]

12. Goñalongs, C.M.; Farina, W.M. Effects of sublethal doses of imidacloprid on young adult honeybee behaviour. PLoS ONE 2015, 10, $\mathrm{e} 0140814$.

13. Woodcock, B.; Isaac, N.; Bullock, J.; Roy, D.B.; Garthwaite, D.G.; Crowe, A.; Pywell, R.F. Impacts of neonicotinoid use on long-term population changes in wild bees in England. Nat. Commun. 2016, 7, 12459. [CrossRef]

14. Forfert, N.; Troxler, A.; Retschnig, G.; Gauthier, L.; Straub, L.; Moritz, R.F.A.; Neumann, P.; Williams, G.R. Neonicotinoid pesticides can reduce honeybee colony genetic diversity. PLoS ONE 2017, 12, e0186109. [CrossRef]

15. Pisa, L.; Goulson, D.; Yang, E.C.; Gibbons, D.; Sánchez-Bayo, F.; Mitchell, E.; Aebi, A.; van der Sluijs, J.; MacQuarrie, C.; Giorio, C.; et al. An update of the Worldwide Integrated Assessment (WIA) on systemic insecticides. Part 2: Impacts on organisms and ecosystems. Environ. Sci. Pollut. Res. 2021, 28, 11749-11797. [CrossRef] [PubMed]

16. Codling, G.; Naggar, Y.A.; Giesy, J.P.; Robertson, A.J. Concentrations of neonicotinoid insecticides in honey, pollen and honey bees (Apis mellifera) in central Saskatchewan, Canada. Chemosphere 2016, 144, 2321-2328. [CrossRef]

17. Chauzat, M.P.; Faucon, J.P.; Martel, A.C.; Lachaize, J.; Cougoule, N.; Aubert, M. A survey of pesticide residues in pollen loads collected by honey bees in France. J. Econ. Entomol. 2006, 99, 253-262. [CrossRef] [PubMed]

18. Škerl, M.I.S.; Bolta, Š.V.; Česnik, H.B.; Gregorc, A. Residues of pesticides in honeybee (Apis mellifera carnica) bee bread and in pollen loads from treated apple orchards. Bull. Environ. Contam. Toxicol. 2009, 83, 374-377. [CrossRef] 
19. Mitchell, E.A.D.; Mulhauser, B.; Mulot, M.; Mutabazi, A.; Glauser, G.; Aebi, A. A worldwide survey of neonicotinoids in honey. Science 2017, 358, 109-111. [CrossRef]

20. Böhme, F.; Bischoff, G.; Zebitz, C.P.W.; Rosenkranz, P.; Wallner, K. Pesticide residue survey of pollen loads collected honeybees (Apis mellifera) in daily internals at three agricultural sites in South Germany. PLoS ONE 2018, 13, e0199995. [CrossRef] [PubMed]

21. Wood, T.J.; Kaplan, I.; Zhang, Y.; Szendrei, Z. Honeybee dietary neonicotinoid exposure is associated with pollen collection from agricultural weeds. Proc. R. Soc. B 2019, 286, 20190989. [CrossRef] [PubMed]

22. Valavanidis, A. Neonicotinoid insecticides. Banned by the European Union in 2018 after scientific studies concluded that harm honey bees. Sci. Rev. 2018, 37, 1-20.

23. Laurino, D.; Manino, A.; Patetta, A.; Porporato, M. Toxicity of neonicotinoids insecticides on different honey bee genotype. Bull. Insectol. 2013, 66, 119-126.

24. Suchail, S.; Guez, D.; Belzunces, L. Characteristics of imidacloprid toxicity in two Apis mellifera species. Environ. Toxicol. Chem. 2000, 19, 1901-1905. [CrossRef]

25. Suchail, S.; Guez, D.; Belzunces, L.P. Discrepancy between acute and chronic toxicity induced by imidacloprid and its metabolites in Apis mellifera. Environ. Toxicol. Chem. 2001, 20, 2482-2486. [CrossRef]

26. Nauen, R.; Ebbinghaus-Kintscherm, U.; Schmuck, R. Toxicity and nicotinic acetylcholine receptor interaction of imidacloprid and its metabolites in Apis mellifera (Hymenoptera: Apidae). Pest Manag. Sci. 2001, 57, 577-586. [CrossRef]

27. Abbassy, M.A.; Nasr, H.M.; Abo-yousef, H.M.; Dawood, R.R. Acute toxicity of selected insecticides and their safety to honey bee (Apis mellifera L.) workers under laboratory conditions. Austin Environ. Sci. 2020, 5, 2.

28. Dai, P.; Jack, C.J.; Mortensen, A.N.; Ellis, J.D. Acute toxicity of five pesticides to Apis mellifera larvae reared in vitro. Pest Manag. Sci. 2017, 73, 2282-2286. [CrossRef] [PubMed]

29. Saleem, M.S.; Huang, Z.Y.; Milbrath, M.O. Neonicotinoid pesticides are more toxic to honey bees at lower temperatures: Implications for overwintering bees. Front. Ecol. Evol. 2020, 8, 556856. [CrossRef]

30. Milone, J.P.; Rinkevich, F.D.; McAfee, A.; Foster, L.J.; Tarpy, D.R. Differences in larval pesticide tolerance and esterase activity across honey bee (Apis mellifera) stocks. Ecotoxicol. Environ. Saf. 2020, 206, 111213. [CrossRef] [PubMed]

31. Rinkevich, F.D.; Margotta, J.W.; Pittman, J.M.; Danka, R.G.; Tarver, M.R.; Ottea, J.A.; Healy, K.B. Genetics, synergists, and age affect insecticide sensitivity of the honey bee, Apis mellifera. PLoS ONE 2015, 10, e0139841. [CrossRef] [PubMed]

32. Manjon, C.; Troczka, B.J.; Zaworra, M.; Beadle, K.; Randall, E.; Hertlein, G.; Singh, K.S.; Zimmer, C.T.; Homem, R.A.; Lueke, B.; et al. Unravelling the molecular determinants of bee sensitive to neonicotinoid insecticides. Curr. Biol. 2018, 28, 1137-1143.e5. [CrossRef] [PubMed]

33. Brito, P.; Elias, M.; Silva-Neto, C.; Sujii, E.; Silva, D.; Gonçalves, B.; Franceschinelli, E. The effects of field-realistic doses of imidacloprid on Melipona quadrifasciata (Apidae: Meliponini) workers. Environ. Sci. Pollut. Res. 2020, 27, 38654-38661. [CrossRef]

34. Decourtye, A.; Devillers, J.; Genecque, E.; Menach, K.L.; Budzinski, H.; Cluzeau, S.; Pham-Delègue, M.H. Comparative sublethal toxicity of nine pesticides on olfactory learning performances of the honeybee Apis mellifera. Arch. Environ. Contam. Toxicol. 2005, 48, 242-250. [CrossRef]

35. Dively, G.P.; Embrey, M.S.; Kamel, A.; Hawthorne, D.J.; Pettis, J.S. Assessment of chronic sublethal effects of imidacloprid on honey bee colony health. PLOS ONE 2015, 10, e0118748.

36. Lawrence, T.J.; Culbert, E.M.; Felsot, A.S.; Hebert, V.R.; Sheppard, W.S. Survery and risk assessment of Apis mellifera (Hymenoptera: Apidea) exposure to neonicotinoid pestocodes in urban, rural, and agricultural settings. J. Econ. Entomol. 2016, 109, 520-528. [CrossRef] [PubMed]

37. Stark, J.D.; Jepson, P.C.; Mayer, D.F. Limitation to use of topical toxicity data for prediction of pesticide side effect in the field. J. Econ. Entomol. 1995, 88, 1081-1088. [CrossRef]

38. Iwasa, T.; Motoyama, N.; Ambrose, J.T.; Roe, R.M. Mechanism for the differential toxicity of neonicotinoid insecticides in the honey bee, Apis mellifera. Crop Prot. 2004, 23, 371-378. [CrossRef]

39. Decourtye, A.; Lacassie, E.; Pham-Delègue, M.H. Learning performances of honeybees (Apis mellifera) are differentially affected by imidacloprid according to the season. Pest Manag. Sci. 2003, 59, 269-278. [CrossRef] [PubMed]

40. Decourtye, A.; Devillers, J. Ecotoxicity of neonicotinoid insecticides to bees. In Insect Nicotinic Acetylcholine Receptors, 1st ed.; Thany, S.H., Ed.; Springer: New York, NY, USA, 2010; pp. 85-95.

41. Yang, E.C.; Chang, H.C.; We, W.Y.; Chen, Y.W. Impaired olfactory associative behavior of honeybee workers due to contamination of imidacloprid in the larval stage. PLoS ONE 2012, 7, e49472. [CrossRef] [PubMed]

42. Decourtye, A.; Armengaud, C.; Renou, M.; Devillers, J.; Cluzeau, S.; Gauthier, M.; Pham-Delegue, M.H. Imidacloprid impairs memory and brain metabolism in the honeybee (Apis mellifera L.). Pestic. Biochem. Physiol. 2004, 78, 83-92. [CrossRef]

43. Medrzycki, P.; Montanari, R.; Bortolotti, L.; Maini, S.; Porrini, C. Effects of imidacloprid administered in sub-lethal doses on honey bee behaviour. Laboratory tests. Bull. Insectol. 2003, 56, 59-62.

44. Forfert, N.; Moritz, R.F.A. Thiacloprid alters social interactions among honey bee workers (Apis mellifera). J. Apic. Res. 2017, 56, 467-474. [CrossRef]

45. Hatjina, F.; Papaefthimiou, C.; Charistos, L.; Dogaroglu, T.; Bouga, M.; Emmanouil, C.; Arnold, G. Sublethal doses of imidacloprid decreased size of hypopharyngeal glands and respiratory rhythm of honeybees in vivo. Apidologie 2013, 44, 467-480. [CrossRef] 
46. Decourtye, A.; Devillers, J.; Cluzeau, S.; Charreton, M.; Pham-Delègue, M.H. Effects of imidacloprid and deltamethrin on associative learning in honeybees under semi-field and laboratory conditions. Ecotoxicol. Environ. Saf. 2004, 57, 410-419. [CrossRef]

47. Faucon, J.P.; Aurières, C.; Drajnudel, P.; Mathieu, L.; Ribière, M.; Martel, A.-C.; Zeggane, S.; Chauzat, M.-P.; Aubert, M.F.A. Experimental study on the toxicity of imidacloprid given in syrup to honey bee (Apis mellifera) colonies. Pest Manag. Sci. 2005, 6 , 111-125. [CrossRef]

48. Yang, E.C.; Chuang, Y.C.; Chen, Y.L.; Chang, L.H. Abnormal foraging behavior induced by sublethal dosage of imidacloprid in the honey bee. J. Econ. Entomol. 2008, 101, 1743-1748. [CrossRef]

49. Schneider, C.W.; Tautz, J.; Grünewald, B.; Fuchs, S. RFID tracking of sublethal effects of two neonicotinoid insecticides on the foraging behavior of Apis mellifera. PLoS ONE 2012, 7, e30023. [CrossRef]

50. Williamson, S.M.; Wright, G.A. Exposure to multiple cholinergic pesticides impairs olfactory learning and memory in honeybees. J. Exp. Biol. 2013, 216, 083931. [CrossRef]

51. Karahan, A.; Çakmak, I.; Hranitz, J.; Karaca, I.; Wells, H. Sublethal imidacloprid effects on honey bee flower choices when foraging. Ecotoxicology 2015, 24, 2017-2025. [CrossRef]

52. Zhang, E.; Nieh, J.C. The neonicotinoid imidacloprid impairs honey bee aversive learning of simulated predation. J. Exp. Biol. 2015, 218, 3199-3205. [CrossRef]

53. Li, Z.; Yu, T.; Chen, Y.; Heerman, M.; He, J.; Huang, J.; Nie, H.; Su, S. Brain transcriptome of honey bees (Apis mellifera) exhibiting impaired olfactory learning induced by a sublethal dose of imidacloprid. Pestic. Biochem. Physiol. 2019, 156, 36-43. [CrossRef]

54. Gooley, Z.C.; Gooley, A.C. Exposure to field realistic concentrations of imidacloprid at different ambient temperatures disrupts non-flight metabolic rate in honey bee (Apis mellifera) foragers. Bull. Insectol. 2020, 73, 161-170.

55. Brandt, A.; Gorenflo, A.; Siede, R.; Meixner, M.; Büchler, R. The neonicotinoids thiacloprid, imidacloprid, and clothianidin affect the immunocompetence of honey bees (Apis mellifera L.). J. Insect Physiol. 2016, 86, 40-47. [CrossRef] [PubMed]

56. Alaux, C.; Brunet, J.-L.; Dussaubat, C.; Mondet, F.; Tchamitchan, S.; Cousin, M.; Brillard, J.; Baldy, A.; Belzunces, L.P.; le Conte, Y. Interactions between Nosema microspores and a neonicotinoid weaken honeybees (Apis mellifera). Environ. Microbiol. 2010, 12, 774-782. [CrossRef]

57. Pettis, J.S.; van Engelsdorp, D.; Johnson, J.; Dively, G. Pesticide exposure in honey bees results in increased levels of the gut pathogen Nosema. Naturwissenschaften 2012, 99, 153-158. [CrossRef]

58. Peng, Y.C.; Yang, E.C. Sublethal dosage of imidacloprid reduces the microglomerular density of honey bee mushroom bodies. Sci. Rep. 2016, 6, 19298. [CrossRef] [PubMed]

59. Alburaki, M.; Steckel, S.J.; Chen, D.; Mcdermott, E.; Weiss, M.; Skinner, J.A.; Kelly, H.; Lorenz, G.; Tarpy, D.R.; Meikle, W.G.; et al. Landscape and pesticide effects on honey bees: Forager survival and expression of acetylcholinesterase and brain oxidative genes, Apidologie 2017, 48, 556-571. [CrossRef]

60. Chaimanee, V.; Evans, J.D.; Chen, Y.; Jackson, C.; Pettis, J.S. Sperm viability and gene expression in honey bee queens (Apis mellifera) following exposure to the neonicotinoid insecticide imidacloprid and the organophosphate acaricide coumaphos. $J$. Insect Physiol. 2016, 89, 1-8. [CrossRef]

61. De Smet, L.; Hatjina, F.; Ioannidis, P.; Hamamtzoglou, A.; Schoonvaere, K.; Francis, F.; Meeus, I.; Smagghe, G.; de Graaf, D.C. Stress indicator gene expression profiles, colony dynamics and tissue development of honey bees exposed to sub-lethal doses of imidacloprid in laboratory and field experiments. PLoS ONE 2017, 12, e0171529. [CrossRef]

62. Gregorc, A.; Alburaki, M.; Rinderer, N.; Sampson, B.; Knight, P.R.; Karim, S.; Adamczyk, J. Effects of coumaphos and imidacloprid on honey bee (Hymenoptera: Apidae) lifespan and antioxidant gene regulations in laboratory experiments. Sci. Rep. 2018, 8 , 15003. [CrossRef]

63. Aufauvre, J.; Misme-Aucouturier, B.; Viguès, B.; Texier, C.; Delbac, F.; Blot, N. Transcriptome Analyses of the Honeybee Response to Nosema ceranae and Insecticides. PLoS ONE 2014, 9, e91686. [CrossRef]

64. Wu, Y.-Y.; Luo, Q.-H.; Hou, C.-S.; Wang, Q.; Dai, P.-L.; Gao, J.; Liu, Y.-J.; Diao, Q.-Y. Sublethal effects of imidacloprid on targeting muscle and ribosomal protein related genes, in the honey bee Apis mellifera L. Sci. Rep. 2017, 7, 15943. [CrossRef] [PubMed]

65. Christen, V.; Shirrmann, M.; Frey, J.E.; Fent, K. Global Transcriptomic Effects of Environmentally Relevant Concentrations of the Neonicotinoids Clothianidin, Imidacloprid, and Thiamethoxam in the Brain of Honey Bees (Apis mellifera). Environ. Sci. Technol. 2018, 52, 7534-7544. [CrossRef]

66. Wu, M.C.; Chang, Y.W.; Lu, K.H.; Yang, E.C. Gene expression changes in honey bees induced by sublethal imidacloprid exposure during the larval stage. Insect Biochem. Mol. Biol. 2017, 88, 12-20. [CrossRef] [PubMed]

67. Tesovnik, T.; Zora, M.; Gregorc, A.; Rinehart, T.; Adamczyk, J.; Narat, M. Immune gene expression in developing honey bees (Apis mellifera L.) simultaneously exposed to imidacloprid and Varroa destructor in laboratory conditions. J. Apicul. Res. 2019, 58, 730-739. [CrossRef]

68. Williams, G.; Troxler, A.; Retschnig, G.; Roth, K.; Yañez, O.; Shutler, D.; Neumann, P.; Gauthier, L. Neonicotinoid pesticides severely affect honey bee queens. Sci. Rep. 2015, 5, 14621. [CrossRef]

69. Wu-Smart, J.; Spivak, M. Sub-lethal effects of dietary neonicotinoid insecticide exposure on honey bee queen fecundity and colony development. Sci. Rep. 2016, 6, 32108. [CrossRef] 
70. Vergara-Amado, J.; Manzi, C.; Franco, L.M.; Contecha, S.C.; Marquez, S.J.; Solano-Iguaran, J.J.; Haro, R.E.; Silva, A.X. Effects of residual doses of neonicotinoid (imidacloprid) on metabolic rate of queen honey bees Apis mellifera (Hymenoptera: Apidae). Apidologie 2020, 51, 1091-1099. [CrossRef]

71. Woyciechowski, M.; Moron, D. Life expectancy and onset of foraging in the honeybee (Apis mellifera). Insectes Soc. 2009, 56, 193-201. [CrossRef]

72. Wu, J.Y.; Anelli, C.M.; Sheppard, W.S. Sub-lethal effects of pesticide residues in brood comb on worker honey bee (Apis mellifera) development and longevity. PLOS ONE 2011, 6, e14720. [CrossRef]

73. Colin, T.; Meikle, W.G.; Wu, X.; Barron, A.B. Traces of a Neonicotinoid Induce Precocious Foraging and Reduce Foraging Performance in Honey Bees. Environ. Sci. Technol. 2019, 53, 8252-8261. [CrossRef] [PubMed]

74. Schippers, M.P.; Dukas, R.; Smith, R.W.; Wang, J.; Smolen, K.; McClellandet, G.B. Lifetime performance in foraging honeybees: Behaviour and physiology. J. Exp. Biol. 2006, 209, 3828-3836. [CrossRef]

75. Vance, J.T.; Williams, J.B.; Elekonich, M.M.; Roberts, S.P. The effects of age and behavioral development on honey bee (Apis mellifera) flight performance. J. Exp. Biol. 2009, 212, 2604-2611. [CrossRef] [PubMed]

76. Schippers, M.P.; Dukas, R.; McClelland, G.B. Lifetime- and caste-specific changes in flight metabolic rate and muscle biochemistry of honeybees, Apis mellifera. J. Comp. Physiol. B 2010, 180, 45-55. [CrossRef]

77. Perry, C.J.; Søvik, E.; Myerscough, M.R.; Arron, A.B. Behavioral Maturation Accelerates Failure of Stressed Honey Bee Colonies. Proc. Natl. Acad. Sci. USA 2015, 112, 3427-3432. [CrossRef]

78. Ushitani, T.; Perry, C.J.; Cheng, K.; Barron, A.B. Accelerated behavioural development changes fine-scale search behaviour and spatial memory in honey bees (Apis mellifera L.). J. Exp. Biol. 2016, 219, 412-418.

79. Chen, Y.R.; Tzeng, D.T.W.; Ting, C.; Hsu, P.S.; Wu, T.H.; Zhong, S.; Yang, E.C. Missins nurse bees-Early transcriptomic switch from nurse bee to forager induced by subltheal imidacloprid. Front. Genet. 2021, 12, 665927. [CrossRef]

80. Belenky, P.; Racette, F.G.; Bogan, K.L.; McClure, J.M.; Smith, J.S.; Brenner, C. Nicotinamide riboside promotes sir2 silencing and extends lifespan via Nrk and Urh1/Pnp1/Meu1 pathways to NAD(+). Cell 2007, 129, 473-484. [CrossRef]

81. Shi, T.; Zhu, Y.; Liu, P.; Ye, L.; Jiang, X.; Cao, H.; Yu, L. Age and Behavior-Dependent Differential miRNAs Expression in the Hypopharyngeal Glands of Honeybees (Apis mellifera L.). Insects 2021, 12, 764. [CrossRef] [PubMed]

82. Laplante, M.; Sabatini, D.M. mTOR signaling at a glance. J. Cell Sci. 2009, 122, 3589-3594. [CrossRef]

83. Hansen, M.; Flatt, T.; Aguilaniu, H. Reproduction, fat metabolism, and life span: What is the connection? Cell Metabol. 2013, 17, 10-19. [CrossRef] [PubMed]

84. Walden, H.; Deans, A.J. The Fanconi anemia DNA repair pathway: Structural and functional insights into a complex disorder. Annu. Rev. Biophys. 2014, 43, 257-278. [CrossRef]

85. Ben-Shahar, Y.; Leung, H.-T.; Pak, W.L.; Sokolowski, M.B.; Robinson, G.E. cGMP-dependent changes in phototaxis: A possible role for the foraging gene in honey bee division of labor. J. Exp. Biol. 2003, 206, 2507-2515. [CrossRef]

86. Yu, G.; Wang, L.G.; Han, Y.; He, Q.Y. clusterProfiler: An R package for comparing biological theme among gene clusters. OMICS J. Integrat. Biol. 2012, 16, 284-287. [CrossRef] [PubMed]

87. Wu, T.; Hu, E.; Xu, S.; Liu, S.; Bo, X.; Yu, G. clusterProfiler 4.0: A universal enrichment tool for interpreting omics data. Innovation 2021, 2, 100141.

88. Seeley, T.D. Adaptive significance of the age polyethism schedule in honeybee colonies. Behav. Ecol. Sociobiol. 1982, 11, 287-293. [CrossRef]

89. Paleolog, J.; Wilde, J.; Siuda, M.; Bąk, B.; Wójcik, Ł.; Strachecka, A. Imidacloprid markedly affects hemolymph proteolysis, biomarkers, DNA global methylation, and the cuticle proteolytic layer in western honeybees. Apidologie 2020, 51, 620-630. [CrossRef]

90. Colgan, T.J.; Fletcher, I.K.; Arce, A.N.; Gill, R.J.; Rodrigues, A.R.; Stolle, E.; Chittka, L.; Wurm, Y. Caste- and pesticide-specific effects of neonicotinoid pesticide exposure on gene expression in bumblebees. Mol. Ecol. 2019, 28, 1964-1974. [CrossRef]

91. Bebane, P.S.A.; Hunt, J.H.; Pegoraro, M.; Jones, A.R.C.; Marchall, H.; Rosato, E.; Mallon, E.B. The effects of the neonicotinoid imidacloprid on gene expression and DNA methylation in the buff-tailed bumblebee Bumbus terrestris. Proc. R. Soc. B 2019, 286, 20190718. [CrossRef]

92. Gao, J.; Jin, S.S.; He, Y.; Luo, J.H.; Xu, C.Q.; Wu, Y.Y.; Hou, C.S.; Wang, Q.; Diao, Q.Y. Physilogical analysis and transcriptome analysis of Asian honey bee (Apis cerana cerana) in response to sublethal neonicotinoid imidacloprid. Insect 2020, 11, 753. [CrossRef] [PubMed]

93. Beadle, K.; Singh, K.S.; Troczka, B.J.; Randall, E.; Zaworra, M.; Zimmer, C.T.; Hayward, A.; Reid, R.; Kor, L.; Kohler, M.; et al. Genomic insights into neonicotinoid sensitivity in the solitary bee Osmia bicornis. PLoS Genet. 2019, 15, e1007903. [CrossRef] [PubMed] 